Int. J. Dev. Biol. 62: 591-604 (2018)

https://doi.org/10.1387/ijdb.180081my

\title{
Cellular senescence in tissue repair: every cloud has a silver lining
}

\author{
MAXIMINA H. YUN* \\ Technische Universität Dresden - DFG Center for Regenerative Therapies Dresden (CRTD) and \\ Max Planck Institute for Molecular Cell Biology and Genetics, Dresden, Germany
}

\begin{abstract}
Cellular senescence, a form of stable cell cycle arrest induced by cellular stress, constitutes a major factor leading to the promotion of pathologies and physiological decays that take place during ageing. However, in recent years evidence has started to emerge supporting a positive role for senescent cells in various physiological processes, from embryonic development to tissue injury responses such as wound healing and tissue repair. Here, we provide an overview of cellular senescence, its negative as well as positive outcomes, with a focus on its impact on tissue repair. Furthermore, we discuss the possibility that cell senescence could contribute to the regeneration of complex structures and explore recent findings with respect to their potential for therapeutic application.
\end{abstract}

KEY WORDS: cellular senescence, development, wound healing, regeneration, salamander

Cellular senescence is a regulated response to various forms of cellular stress whereby cells undergo a permanent cell cycle arrest, highly refractory to mitogens, as well as a series of phenotypic transformations. Initially described as a process which limits the replicative lifespan of cells in culture upon reaching the 'Hayflick limit' (Hayflick, 1965, Hayflick and Moorhead, 1961), cell senescence is now recognised as a universal anti-proliferative response to a wide range of stimuli including DNA damage, oncogene activation, telomere erosion, protein misfolding, oxidative damage and exposure to extracellular signals such as mitogens and cytokines, which can happen at any point during the lifespan of a cell (Fig. 1)(Campisi, 2013, Kuilman et al., 2010, Rodier and Campisi, 2011, Serrano et al., 1997, Yun, 2015). In the face of excessive or irreparable cellular and genotoxic stress, cell senescence acts as an alternative fate to apoptosis, triggering a state of permanent cell cycle arrest that prevents the propagation of compromised cells. As such, it constitutes a powerful cell-autonomous mechanism of tumour suppression (Campisi, 2005). However, unlike apoptosis, cellular senescence leads to the generation of cells which remain metabolically active within tissues and secrete a host of molecules, collectively known as the senescence-associated secretory phenotype (SASP), that can alter their microenvironment with important consequences for a wide range of biological processes from development to ageing. Through their non cell-autonomous functions, senescent cells have been shown to affect cell migration and growth, tissue architecture, cell plasticity, recruitment of immune cells and inflammatory responses. Recent evidence has linked these functions to physiologically detrimental processes such as the promotion of tumourigenesis and inflammation. Furthermore, there is mounting evidence that cellular senescence is also a major contributor to the Ageing process, driving age-related pathologies as well as age-related declines in regenerative responses (Baker et al., 2016, van Deursen, 2014, Yun, 2015). Yet, at the same time, compelling evidence is emerging supporting a beneficial role for senescent cells in a variety of contexts including embryonic development (Chuprin et al., 2013, Davaapil et al., 2017, Munoz-Espin et al., 2013, Storer et al., 2013, Villiard et al., 2017), wound healing (Demaria et al., 2014, Jun and Lau, 2010) and additional responses to tissue injury (Kong et al., 2012, Krizhanovsky et al., 2008, Meyer et al., 2016, Ritschka et al., 2017, Yun et al., 2015). Such seemingly conflicting observations could be reconciled by taking into account the phenotypic complexity of different senescent states, particularly with regard to their dynamic secretory phenotype. Understanding the molecular nature of the senescent state, its evolution, targets and regulation in space and time, will provide a base from which to elucidate the beneficial and detrimental aspects of the senescence programme and how to use this knowledge in respect of therapeutic applications in cancer, ageing and regeneration.

Abbreviations used in this paper: SASP, senescence-associated secretory phenotype.

*Address correspondence to: Maximina H. Yun. Technische Universität Dresden - DFG Center for Regenerative Therapies Dresden (CRTD). Fetscherstraße 105,
01307 Dresden, Germany.Tel: +49 $(0) 351458$ 82022. Fax: +49 $(0) 351458$ 82059. E-mail: maximina.yun@ @ tu-dresden.de - (iD https://orcid.org/0000-0001-9019-2453 


\section{Molecular basis of cellular senescence}

At the molecular level, the establishment of cellular senescence requires activation of classical cell cycle inhibition pathways such as p53 and/or the cyclin-dependent kinase inhibitors p21 CDKN1A, p16 ${ }^{\text {CDKN2AINK4A }}$ and p15 ${ }^{\text {CDKN2BINK4B }}$, critical enforcers of cell cycle arrest (Fig. 1). Activation of the p53 pathway results in the hypophosphorylation of the S-phase transition regulator retinoblastoma $(\mathrm{Rb})$ and pocket proteins $\mathrm{p} 130$ and p107, mounting a barrier to DNA replication (Burkhart and Sage, 2008, Stein et al., 1990). The CDKN2A locus plays a critical role in this process as it encodes both $\mathrm{p} 16^{\mathrm{INK} 4 \mathrm{~A}}$ and another important senescence inducer, p14 ARF

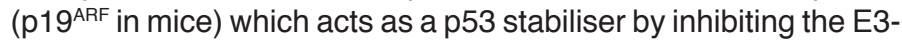
ubiquitin ligase that normally targets p53 for degradation, MDM2 (Kamijo et al., 1998, Shay et al., 1991). Yet, there are examples of senescence induction that do not depend on p53 but solely on p16 ${ }^{\text {INK4A }}$ or p2 $1^{\text {CDKN1A, }}$, and cases in which $p 15^{\text {INK4B }}$ can take over the functions of p16 INK4A (Krimpenfort et al., 2007). The importance of these molecules as effectors of the senescence programme is highlighted by the consequences of their loss, which results in senescence bypass and tumourigenesis. Furthermore, while different senescence-promoting stimuli are known to use different signalling pathways, these ultimately converge in the activation of the cell cycle inhibition machinery. For example, senescence induced by the oncogene RAS initially involves the activation of a MAPK cascade, which results in an increase in p53 activation and p16 upregulation (Lin et al., 1998). Likewise, telomere erosion and other forms of DNA damage induce senescence following DNA damage recognition and activation of the kinases ATM and ATR, which stimulates the downstream kinases CHK1 and CHK2 resulting in the phosphorylation-mediated activation of the p53/p21 axis (d'Adda di Fagagna et al., 2003, Herbig et al., 2004). In certain contexts, the DNA-damage response can result in expression of interferon beta (IFN $\beta$ ) via ATM activation, which leads to p53 activation and senescence promotion (Yu et al., 2015). Additionally, T-helper derived cytokines such as interferon gamma (IFN $\gamma$ ) and tumour necrosis factor (TNF) can induce a G1 senescent arrest mediated by the activation of $\mathrm{p} 16$ and $\mathrm{Rb}$ hypophosporylation $(\mathrm{Br}$ aumuller et al., 2013). Lastly, senescence induced by oncogenes such as BRAFV600E can lead to the direct activation of p16 expression (Zhu et al., 1998), whereas senescence induced by the loss of the tumour suppressor PTEN is initiated through activation of mTORC pathway but eventually leads to upregulation of $\mathrm{p} 16$ and ARF expression (Alimonti et al., 2010). The involvement of mTORC in oncogene-mediated senescence induction hints at a causal relationship between senescence and autophagy. Indeed, inhibition of autophagy has been shown to delay HRAS ${ }^{\mathrm{G} 12 \mathrm{~V}}$ induced senescence (Young et al., 2009), leading to the suggestion that autophagy could contribute to the generation of metabolites to fuel the synthesis of SASP factors, facilitating senescence. More recent experiments described a role for autophagy in lamin B1 degradation (Dou et al., 2016), a trigger of p53 activation which leads to proliferative arrest and senescence (Shimi et al., 2011). However, recent data also suggests that inhibition of autophagy can promote, rather than impair, cellular senescence in proliferating cells (Garcia-Prat et al., 2016), as discussed in the next section. These paradoxical observations were recently reconciled by data demonstrating that autophagy leads to the activation of factors that have opposite effects on cellular senescence and therefore autophagy inhibition can result in different outcomes depending on the cellular context (Kang and Elledge, 2016). In particular, selective autophagy suppresses cellular senescence through degradation of GATA4 (Kang et al., 2015), a transcription factor that regulates
Permanent cell cycle arrest

\begin{tabular}{l}
\hline Inducers \\
- Telomere attrition (RS) \\
- Oncogene activation (OIS) \\
- DNA damage \\
- Reactive oxygen species \\
- Unfolded protein response \\
- Cytokines \\
- Mitogens
\end{tabular}

Molecular mediators

- p53

- $p 21$

$\cdot \mathrm{RB}$

- p16 $6^{\text {INK4A }}$ (also p15 INK4B)

$\cdot \mathrm{p} 14^{\mathrm{ARF}}$

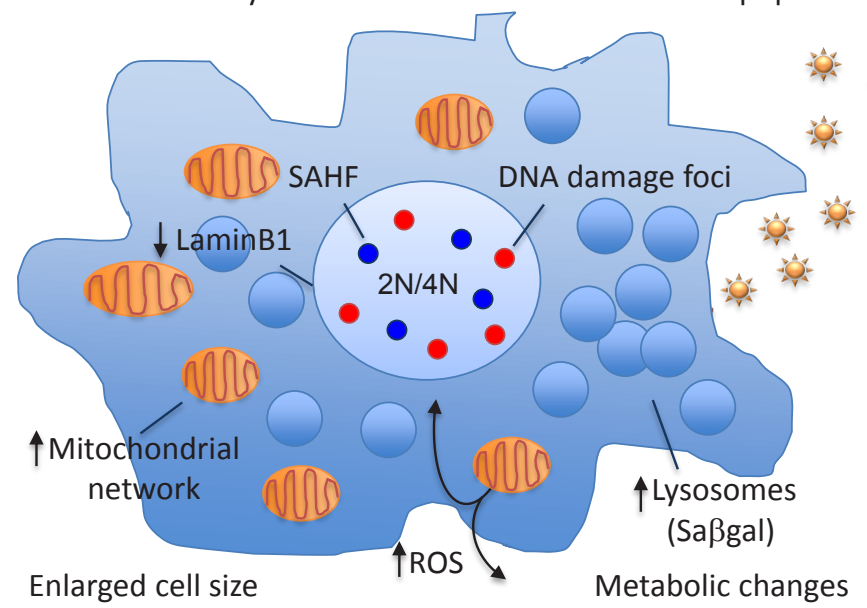

resistance to apoptosis

Fig. 1. Features of cellular senescence. Senescent cells are characterised by a permanent cell cycle arrest, induced by a range of different stimuli including telomere attrition, DNA damage, oncogene activation and exposure to extracellular signals such as cytokines and mitogens. These stimuli result in the activation of key cell cycle regulators such as p53, p21, p16 and p14ARF, leading to cell cycle exit in either G1 or G2 (with $2 \mathrm{~N}$ or $4 \mathrm{~N}$ DNA content) and the acquisition of phenotypic changes including apoptosis resistance, expansion of mitochondrial and lysosomal networks, increased lysosomal senescence-associated $\beta$-galactosidase (Saßgal) activity, production of reactive oxygen species (ROS), metabolic reshaping, enlarged cell size, heterochromatin changes resulting in the appearance of senescence-associated heterochromatic foci (SAHF), presence of DNA damage foci, decrease in LaminB1, and expression of a senescence-associated secretory phenotype (SASP) which includes cytokines, growth factors and matrix remodelling proteins. Manifestation of these hallmarks varies according to the nature of the senescence stimulus, the cell type and time from induction. Through the SASP, senescent cells can modify their microenvironment, with important consequences for physiological processes such as inflammation, tumourigenesis, morphogenesis and regenerative responses. 
the SASP, while general autophagy facilitates senescence through mTOR and p53 activation.

While the activation of a cell cycle inhibitory response is common to all senescent cells, the critical determinants of such inhibition vary according to the nature of the cell, the initial stimulus and even the species, both in vitro and in vivo. This is exemplified by the p21-dependent but p16-independent senescence observed in the mesonephros and apical ectodermal ridge during mouse development (Munoz-Espin et al., 2013, Storer et al., 2013), which contrasts with the p16-dependent senescence induced during wound healing (Demaria et al., 2014) and many stem cell populations in ageing contexts (Baker et al., 2016, Chang et al., 2016, Sousa-Victor et al., 2014). Additionally, cultured mouse embryonic fibroblasts rely on $\mathrm{p} 19^{\mathrm{ARF}}$ for the maintenance of the senescent state, yet human fibroblasts depend largely on p16 (Collins and Sedivy, 2003, Sharpless and Sherr, 2015). Differences in molecular requirements for the induction of senescence are also found according to the stage of the cell cycle from which a cell enters senescence. Although traditionally described as an irreversible form of $\mathrm{G} 1$ arrest, recent studies have shown that senescence can also take place during the G2 phase of the cell cycle through p21mediated inhibition of mitotic CDK complexes (Baus et al., 2003, Gire and Dulic, 2015, Herbig et al., 2004). When this mechanism fails, mitotic slippage can occur, leading to cells with $4 \mathrm{~N}$ content which undergo a senescence arrest in the subsequent G1 phase which depends on $\mathrm{p} 53 / \mathrm{Rb}$ for its induction but relies primarily on p16 for its maintenance (Johmura et al., 2014). Hence, mechanistically, senescence induced in $\mathrm{G} 2$ is distinct from the $\mathrm{G} 1$ arrest which is caused by adaptation to the spindle checkpoint or by defects in cytokinesis (Gire and Dulic, 2015). Despite these differences, senescent cells invariably display high levels of at least one of the central cell cycle inhibitors, a feature that constitutes a molecular hallmark of the senescent state.

\section{Hallmarks of cellular senescence}

Reflecting the multiplicity of triggers and molecular pathways involved in its establishment, cellular senescence is associated with a repertoire of phenotypically diverse cellular states whose characteristics depend on the mechanism of induction, the nature of the cell and the time since the initial stimulus, and whose manifestation ultimately determines the physiological impact of the senescent cell. Yet, there are features shared by the majority of senescent states described so far (Fig. 1). The most prominent among them is a persistent cell cycle arrest that, in contrast to quiescence, is unresponsive to mitogenic signals and is governed by the molecular mediators discussed above. Indeed, this is the defining hallmark of cellular senescence. Such a robust cell cycle arrest may also be found in terminally differentiated cells, however senescent cells are characterised by a series of additional features that distinguish them from their differentiated counterparts. These include morphological changes (increase in cell volume, flattened morphology in culture), an expansion of mitochondrial and lysosomal networks (leading to high levels of senescence-associated- $\beta$-galactosidase -SAßgal- activity, a widely used senescent cell marker (Dimri et al., 1995)), increases in metabolic rate, production of reactive oxygen species (ROS), a marked resistance to apoptosis, epigenetic rearrangements, persistent DNA damage foci (depending on the stimulus and frequently containing DNA damage sensors such as $\gamma \mathrm{H} 2 \mathrm{AX}$ and 53BP1 (Rodier et al., 2011)) and the acquisition of a senescence-associated secretory phenotype (SASP) which comprises growth factors, cytokines, chemokines and matrixremodelling proteins (MMPs) (Acosta et al., 2008, Kuilman et al., 2008) and is responsible for the non cell-autonomous functions of senescent cells (Coppe et al., 2008). Some of these features are characteristic of certain types of senescence, while others (such as cell cycle inhibitor expression, lack of proliferation markers and SA $\beta$ gal activity) are common to all.

In addition to the aforementioned hallmarks, many examples of the senescent state exhibit a spatial reorganisation of heterochromatin into senescence-associated heterochromatic foci (SAHF). This accompanies the profound alterations in gene expression seen in senescent cells (Chandra and Narita, 2013, Rai and Adams, 2013). The repressive chromatin marks tri-methylated histone 3 in lysine 9 and $27, \mathrm{H} 3 \mathrm{~K} 9 \mathrm{me} 3$ and $\mathrm{H} 3 \mathrm{~K} 27 \mathrm{me} 3$ respectively, are segregated from each other within SAHF (Chandra and Narita, 2013), forming discrete spatial domains in a process that requires LaminB1 downregulation and relocalisation within the nucleus (Sadaie et al., 2013). In addition, the histone variants $\mathrm{H} 3.3$ and macroH2A have been shown to increase during senescence, suggesting that they may play a role in the maintenance of chromatin structure within senescent cells (Rai and Adams, 2013). Such heterochromatin changes are functionally relevant, as highlighted by the requirement of H3K9me-dependent heterochromatin formation for the silencing of growth factor promoting genes mediated by $\mathrm{Rb}$ during oncogene-induced senescence. This process is mediated in part by the histone methyltransferase Suv391, and its failure results in tumour development (Braig et al., 2005).

Another common feature of senescent cells is a marked resistance to apoptosis, which is molecularly determined by expression of pro-survival, anti-apoptotic regulators such as Bcl-XI and Bcl-2 (Wang, 1995), downregulation of apoptotic effectors such as caspase-3 (Marcotte et al., 2004), or inability to stabilise p53 to the levels required for eliciting the apoptotic programme (Seluanov et al., 2001). In this connection, it is worth noting that cell senescence constitutes an alternative response to apoptosis upon DNAdamage and cell stress, and that they have common molecular activators such as p53. The balance between senescence and apoptosis is determined by the cell type, the type and magnitude of the damage, and established at the molecular level by the extent of p53 expression, post-translational modifications and activation. Furthermore, interfering with the ability of a cell to undergo apoptosis results in a switch towards senescence. Moreover, downregulating or inhibiting anti-apoptotic regulators in senescent cells can make them undergo apoptosis. This is an important notion in the light of the recent development of senolytics (molecules that specifically lead to the elimination of senescent cells) such as ABT-263 and ABT-737, specific inhibitors of the anti-apoptotic proteins BCL-2 and $\mathrm{BCL}-\mathrm{XL}$ which act by inducing apoptosis specifically in senescent cells (Chang et al., 2016, Yosef et al., 2016).

The identification of these hallmarks opened the door to the detection, characterization and targeting of senescent cells in in vivo contexts. Thus, detection of senescence-associated $\beta$ galactosidase enzymatic activity at $\mathrm{pH} 6$ (a suboptimal $\mathrm{pH}$ for the activity of this lysosomal enzyme, which normally operates at $\mathrm{pH}$ 4-4.5, but one that allows its detection in cells with high activity such as senescent cells (Lee et al., 2006)), combined with expression of p16 INK4A, p19ARF, p21 or p53, lack of proliferation markers (eg. nucleotide analogue incorporation or decreased levels of Ki67 
or PCNA), intracellular lipofuscin accumulation and expression of SASP components, have been instrumental in establishing that senescence does not simply constitute a cell culture singularity but occurs in various in vivo settings (Evangelou et al., 2017, Yun, 2015). Furthermore, senescence-associated features have facilitated the development of functional tools, including genetic labelling and ablation cassettes based on p16 regulatory regions (Baker et al., 2011, Burd et al., 2013, Demaria et al., 2014) and senolytic molecules (Chang et al., 2016, Yosef et al., 2016).

\section{Enter the senescence-associated secretory phenotype(SASP)}

Among the hallmarks of senescence, perhaps the most relevant to its diverse physiological roles is the secretory phenotype. The SASP constitutes a highly dynamic entity which develops gradually following the induction of senescence and is found in most senescent cells reported so far, both in vitro and in vivo (Coppe et al., 2008, Ito et al., 2017). SASP factors include growth factors (eg. TGF $\beta$, HGF, VEGF, PDGF), cytokines (eg. interleukins such as IL-1, IL-6 and IL8), chemokines (eg. monocyte chemoattractant protein 1, MCP-1), and proteases (eg. cathepsins, matrix metalloproteinases)(Acosta et al., 2013, Coppe et al., 2010, Coppe et al., 2008, Ito et al., 2017). A hierarchy is evident among the SASP factors, as some of them are required for the maintenance whilst others for the induction of the secretory phenotype. This is the case with IL-1, which is an essential trigger of the SASP in oncogene-induced senescence (Acosta et al., 2013). Expression of IL $1 \alpha$ can activate the $\mathrm{c} / \mathrm{EBP} \beta$ and NFKB pathways, which cooperatively regulate SASP components in various senescence contexts (Acosta et al., 2013, Kang et al., 2015, Kuilman et al., 2008 ), resulting in induction of the SASP. Other factors, such as IL-6 and CXCR2-binding chemokines, can form positive feedback loops that reinforce the expression of the SASP as well as the growth arrest (Acosta et al., 2008, Kuilman et al., 2008), whereas the TGF $\beta$ ligands VEFG, CCL2 and CCL20 have been shown to regulate cell cycle inhibitors p15 and p21 (Acosta et al., 2013). Additionally, IL-1 and TGF $\beta$ cooperate to promote the production of ROS in senescent cells (Hubackova et al., 2012). Thus, beyond the effects it may have in neighbouring cells, the SASP helps reinforcement of the senescent state.

Arguably the most prominent aspect of the SASP is its non cell-autonomous nature, which enables senescent cells to communicate with or modify their microenvironment determining their functional impact. Through the SASP, senescent cells can induce paracrine senescence in their neighbours, via a TGF $\beta$, IL-1 and ROS-dependent 'bystander' mechanism which occurs in vitro and in vivo (Acosta et al., 2013, Hubackova et al., 2012, Nelson et al., 2012, Yun et al., 2013). In addition, the SASP underlies complex interactions between senescent cells and the immune response. For example, it can drive the recruitment and activation of immune cells, including monocytes/macrophages, NK and T-cells, leading to the subsequent elimination of senescent cells (Sagiv and Krizhanovsky, 2013). During oncogene-induced senescence, this immune surveillance mechanism has recently been shown to rely on a proinflammatory SASP developed at late stages following senescence induction, which is actively suppressed by Notch1 signaling at earlier stages (Hoare et al., 2016). Senescent cell clearance has been shown to act as an anti-tumourigenic mechanism: senescence of pre-malignant hepatocytes promotes their clearance by CD4+Tcells and macrophages and prevents cancer progression (Kang et al., 2011); likewise, induction of p53-dependent senescence in p53-/- liver carcinomas can elicit tumour regression, dependent on the clearance of the senescent cells (Xue et al., 2007). Additionally, the SASP can regulate immune cells directly. In a p53-dependent manner, senescent hepatic stellate cells secrete factors that skew macrophage polarization towards a pro-inflammatory M1 type, which then contributes to tumour suppression (Lujambio et al., 2013). Notwithstanding these anti-tumourigenic functions, the SASP has been shown to contribute to tumour progression through a variety of mechanisms, including the promotion of malignant cell growth in culture (Krtolica et al., 2001) and in xenografts through the secretion of mitogens such as HGF (Liu and Hornsby, 2007), the generation of a pro-tumourigenic environment via promotion of tissue damage such as MMP-dependent increases in the permeability of tumour capillaries (Liu and Hornsby, 2007), and the promotion of epithelial-mesenchymal transitions (EMT)(Canino et al., 2012, Coppe et al., 2008, Laberge et al., 2012), a mechanism dependent on senescence-derived IL-6 and IL-8 in vitro (Coppe et al., 2008), which can facilitate invasion and metastasis. Furthermore, due to its capacity to alter the microenvironment and promote inflammation (Hoenicke and Zender, 2012), the SASP has been proposed to contribute to tissue malfunction and degeneration.

These considerations raise two important questions. First, how can we rationalise these seemingly contradictory effects of the SASP? It is likely that the answer to this question lies within the nature of the SASP, which is highly context-dependent. Such a variable nature is likely responsible for the multiple, functionally antagonistic outcomes associated with cell senescence and suggest that a deep understanding of the specific senescence setting is required to determine its physiological impact. Second, given the wide range of detrimental effects associated with senescent cells, what burdens do they impose on an organism, and are there any silver linings to their functions?

\section{A causal link between cellular senescence and ageing}

Throughout their lifespan, mammals accumulate senescent cells in various vital organs and tissues including skin, heart, lung, liver, spleen and kidney (Wang et al., 2009, Yang and Fogo, 2010). Whether this is due to decreases in functionality within the senescence clearance system, increases in the rate of senescent cell generation or loss of identification cues in senescent cells that may allow them to escape from immunesurveillance is not yet known (Burton and Krizhanovsky, 2014). Nevertheless, what is clear is that their accumulation is responsible for numerous decays in tissue structure and function that occur during Ageing. Compelling evidence from mouse models has recently established a casual link between the accumulation of senescent cells and a number of age-related disorders. In a seminal study by Van Deursen and co-workers, genetic elimination of $\mathrm{p} 16^{+}$senescent cells in mice with a progeroid background caused by BubR1 deficiency was able to delay the onset of age-related disorders including cataracts, sarcopenia, osteoporosis and subcutaneous fat loss (Baker et al., 2011), suggesting that cellular senescence is an important contributor to age-related decay. In this model, senescent cell elimination is achieved through expression of the INK-ATTAC transgene, which encodes a FKBP-Caspase8 fusion protein under the control of a senescence-responsive p16 promoter element (Baker et al., 2016, Baker et al., 2011). Upon treatment with the synthetic drug 
AP20187, FKBP dimerisation leads to caspase activation and apoptosis induction in senescent cells (Baker et al., 2016, Baker et al., 2011). This transgene was subsequently used to study the effects of senescent cell elimination during normal Ageing in wild type mice (Baker et al., 2016). Continuous drug treatment from one year of age onwards led to delays in tumourigenesis, attenuated age-related decay in several organs including kidney, heart and fat, and lead to significant (up to 30\%) lifespan extension (Baker et al., 2016). Moreover, recent evidence supports a direct role for cell senescence in the promotion of additional age-related disorders such as atherosclerosis (Childs et al., 2016), allopecia (Yosef et al., 2016), pulmonary fibrosis (Schafer et al., 2017) and osteoarthritis (Jeon et al., 2017). Together, these studies established senescence as an important cause of age-related organismal deterioration and led to the proposal that removal of senescent cells could prevent or delay tissue dysfunction and extend healthspan. This idea opened the door to the development of therapeutic strategies based on selective senescent cell elimination. These comprise the use of senolytics (as mentioned above), counteracting the effects of negative SASP components, and enhancing or engineering the immune system to promote senescent cell clearance. So far, senolytic treatment appears to be the most promising strategy, with several molecules that have been shown to decrease senescent cell populations in vivo without apparent side effects. These include the aforementioned apoptotic inhibitors ATB-263 (also known as Navitoclax) and ABT-737, UBX0101, and the peptide-mediated induction of p53-dependent apoptosis. In addition, a senolytic regime comprising treatment with dasatinib and quercetin has been shown to target certain types of senescent populations, though not all. A key issue with this (and other) strategies is the heterogenic nature of senescent cell populations. It is possible that, in practice, treatment may require the combination of several compounds or strategies. The two remaining approaches are as yet in their infancy, and will require the identification of critical mediators of specific negative functions of senescent cells (highly context-dependent), and the identification of specific senescent cell surface markers or 'eat me' signals that could be applied in the engineering of immune cells for improved senescent cell clearance.

\section{Senescence in regenerative decays}

Further extending its relevance to age-related deterioration, senescent progenitors or stem cells have also been shown to accumulate in vivo in aged tissues and in progeroid mouse models. Early studies had already suggested that they key senescence inducerp 16 increased with age in regenerative progenitors. Notably, its overexpression contributes to the replicative failure of many regenerative cell types (Krishnamurthy et al., 2006, Molofsky et al., 2006), while its downregulation or genetic deletion ameliorates age-associated functional and proliferative impairments in stem and progenitor cells (Braun et al., 2012, Janzen et al., 2006), suggesting that cellular senescence could play a role in the decline in regenerative capacity with aging. More recently, direct evidence of such a role came from studies in murine muscle regeneration, which revealed that geriatric muscle stem cells (MuSC) lose their reversible quiescent state during aging by undergoing cellular senescence (Cosgrove et al., 2014, Sousa-Victor et al., 2014). This switch, which renders MuSC unable to activate and expand upon muscle injury, is triggered by an age-related increase in p38 pathway activation combined with the loss of polycomb repres- sive complex activity, resulting in increased p16 expression and senescence induction. Pharmacological inhibition of p38 or specific silencing of $\mathrm{p} 16$ in geriatric satellite cells restores both their reversible quiescence and regenerative functions (Cosgrove et al., 2014, Sousa-Victor et al., 2014). Furthermore, systemic treatment with the senolytic compound ABT-263 has also been shown to improve MuSC-based regeneration in ageing mice (Chang etal., 2016, Yosef et al., 2016). These beneficial effects of senescent cell elimination have also been observed in other systems in which regenerative capacity declines with age, including haematopoietic (Chang et al., 2016), adipose (Xu et al., 2015) and mesenchymal stem cells (MSC)(Li et al., 2017). In the latter, it has recently been shown that the levels of the transcription factor FoxP1 decline during Ageing, leading to increases in p16 expression and MSC senescence. Conditional deletion of FoxP1 in mice promotes $\mathrm{p} 16$ derepression and MSC senescence resulting in decreased bone mass and loss of MSC self-renewal capacity (Li et al., 2017). Lastly, a recent study reported a role for autophagy in maintaining MuSC quiescence by preventing senescence. Failure of autophagy in aged satellite cells, or genetic impairment of autophagy in young cells, causes entry into senescence by loss of proteostasis, resulting in functional and population declines in MuSC. Importantly, re-establishment of autophagy prevents senescence in MuSC, restoring their regenerative potential (Garcia-Prat et al., 2016). Together, these studies suggest that maintenance of the quiescent state relies on the active repression of senescence pathways, and that cellular senescence, in a cell-autonomous manner, is a major contributor to the age-related decline in regenerative abilities.

Aside from its cell-autonomous role, cell senescence has been proposed to affect regenerative capacities through the SASP, by promoting tissue degeneration, niche alterations, progenitor malfunction or inflammation (Yun, 2015). In support of this idea, a negative role for senescent adipogenic progenitors has been described during ageing, whereby these cells secrete Activin A leading to inhibition of adipogenesis in non-senescent progenitors in vivo (Xu et al., 2015). Furthermore, recent studies analysing the development of osteoarthritis have identified senescence as a negative driving factor of such pathology, which acts through the promotion of an anti-regenerative environment, dependent on MMP secretion, that affects cartilage development (Jeon et al., 2017). Thus, besides its direct effects, senescent cells can promote regenerative declines indirectly, through their paracrine activities.

\section{Shifting paradigms}

Such a wide range of detrimental outcomes has recently ignited discussions on the evolutionary rationale for cellular senescence. While it constitutes a tumour-suppressor mechanism, the SASP can be tumour-promoting. Furthermore, the organism already possesses an alternative, and arguably more powerful, tumoursuppression mechanism: apoptosis. How then to explain the evolutionary persistence of cell senescence? One possibility is that the negative effects of cellular senescence are chiefly manifested during the post-reproductive period and thus avoid natural selection. Alternatively, senescent cells could play positive roles in physiological contexts. Indeed, in the past few years senescent cells have been found to contribute to several major processes including embryonic development (Munoz-Espin et al., 2013, Storer et al., 2013), pancreatic $\beta$-cell function (Helman et al., 2016) and responses to tissue injury such as wound healing (Demaria et 
al., 2014, Jun and Lau, 2010), fibrosis restriction following tissue injury (Krizhanovsky et al., 2008, Meyer et al., 2016) and tissue homeostasis (Ritschka et al., 2017), highlighting the numerous beneficial facets of cellular senescence.

\section{The silver linings of cellular senescence}

\section{Senescence in development}

Senescent cells are found during restricted time-windows during the development of several structures in most vertebrates (Fig. 2), from amniotes (birds and mammals) to anamniotes (amphibian and fishes)(Chuprin et al., 2013, Davaapil et al., 2017, Munoz-Espin et al., 2013, Nacher et al., 2006, Storer et al., 2013, Villiard et al., 2017). Their developmental functions have been well characterised in structures such as the mouse and amphibian embryonic kidney, where they are part of a mechanism that promotes the degeneration of transient kidney forms (mammalian mesonephros and amphibian pronephros) to give rise to the ensuing, more mature kidney system (Davaapil et al., 2017, Munoz-Espin et al., 2013). Senescence is induced in pro- or mesonephric tubules at particular developmental stages, spreads through the structure with time, and leads to recruitment of monocytes/macrophages that results in senescent cell clearance and associated degeneration of the structure (Davaapil et al., 2017, Munoz-Espin et al., 2013). Cells within the apical ectodermal ridge (AER) of the mouse limb have also been shown to undergo senescence, which has been proposed to affect the underlying limb mesenchyme through paracrine cues that modulate growth and patterning. As in kidney development, these cells remain within the structure until their immune-mediated removal at later developmental stages (Storer et al., 2013). To date, the collection of studies addressing their roles in various systems suggest that senescent cells contribute to tissue remodelling during development by three mechanisms: promotion of structural degeneration (mediated by macrophage-dependent elimination of senescent cells, exemplified by the embryonic kidney), balance of cell populations (senescence-mediated growth arrest of a particular cell population favouring growth of an alternate one, exemplified by the endolymphatic sac), and morphogenetic signalling (mediated by the SASP and controlled by immune-dependent clearance, exemplified by the mouse AER). In most cases analysed, the enforcement of cell cycle arrest is achieved through p21, and is independent of DNA-damage and p16, although p15 expression is detected in the mouse mesonephros and endolymphatic sac (Munoz-Espin et al., 2013, Storer et al., 2013), and p53 in the axolotl pronephros (Davaapil et al., 2017). The signalling pathways involved in triggering developmental senescence are less conserved however. For example, TGF $\beta$ plays a key role in promoting senescence in the mouse mesonephros, salamander pronephros and Xenopus cement gland, while AER senescence relies on activation of ERK signalling in the underlying mesenchyme but is dispensable for pronephros generation. Distinct signalling could be associated with eliciting different types of senescence, which play equally different roles. Importantly, pharmacological inhibition of these signalling pathways or genetic disruption of p21 leads to loss of senescence accompanied by developmental abnormalities in various structures and organisms, suggesting that senescent cells do have a significant role in tissue remodelling during vertebrate development (Davaapil etal., 2017, Munoz-Espin etal., 2013, Storer etal., 2013). However, it is noteworthy that in all cases analysed, functional defects are only observed transiently and the organisms survive without apparent developmental defects, due to the existence of compensatory mechanisms. These include apoptosis, which has been proposed to replace the functions of developmental senescence in absence of p21 (Munoz-Espin et al., 2013, Storer et al., 2013). Another interesting observation is that, while some functions of developmental senescence are conserved across vertebrates (such as embryonic kidney degeneration), others are not (such as the AER, which does not undergo senescence during amphibian limb development (Yun et al., 2015)). Furthermore, senescence occurs during the development of structures that are not present in amniotes, such as the amphibian cement gland (Davaapil et al., 2017). Together, these observations have several implications.

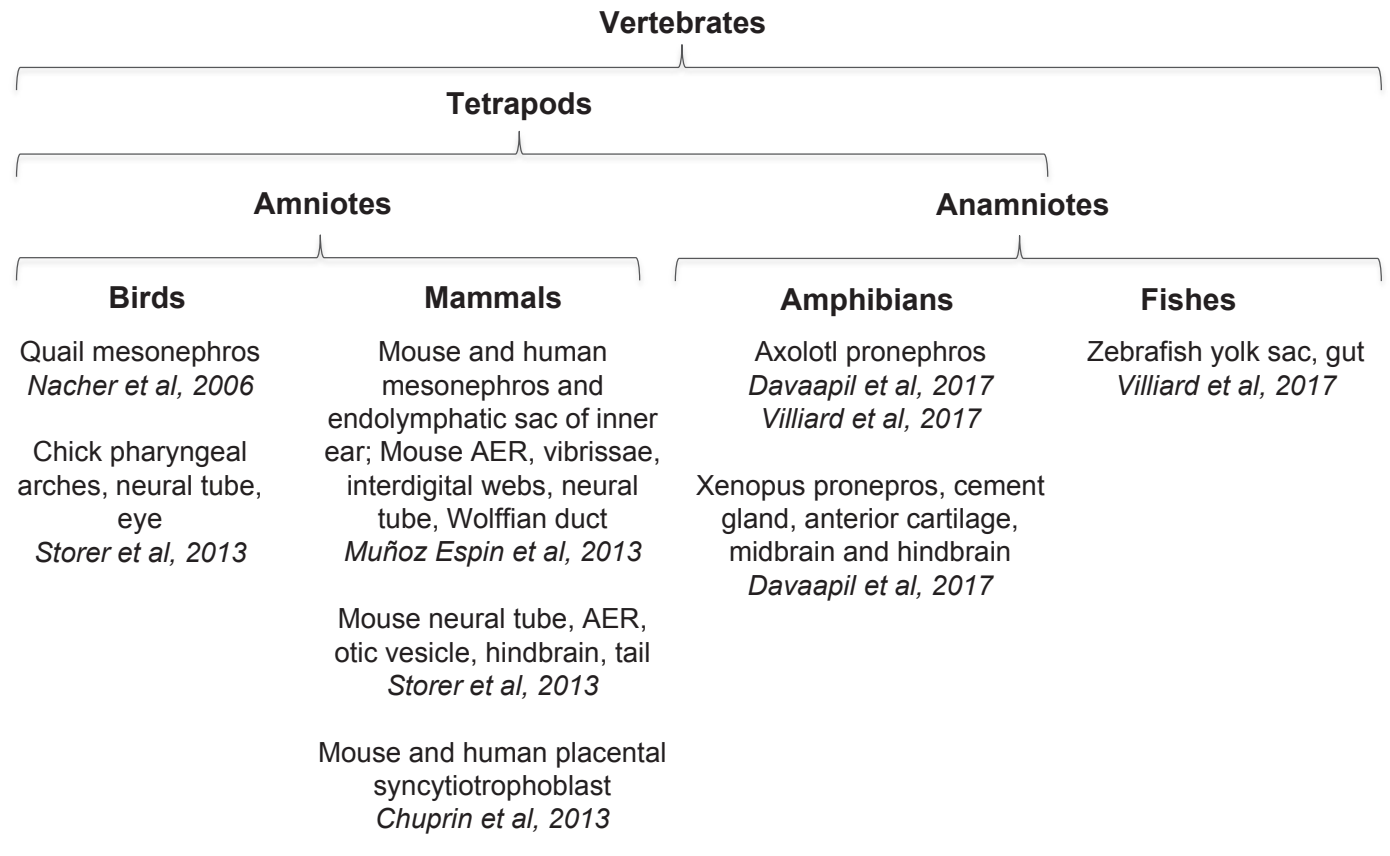

Fig. 2. Programmed cellular senescence is intrinsic to vertebrate development. Senescent cells are found during limited time windows during the development of multiple structures across vertebrates, including in amniotes and anamniotes. These cells can contribute to tissue remodelling through the promotion of tissue degeneration, population balance or delivery of morphogenetic signals, as exemplified by the development of the embryonic kidney (mouse mesonephros and axolotl pronephros), the endolymphatic sac of the inner ear, and the mouse limb. 
TABLE 1

\section{CELLULAR SENESCENCE IN PHYSIOLOGICAL CONTEXTS OF TISSUE INJURY}

\begin{tabular}{|c|c|c|}
\hline Wound healing & Tissue repair/homeostasis & Regeneration \\
\hline $\begin{array}{l}\text { Alleviation of fibrosis in skin by } \\
\text { CCN1-mediated induction of } \\
\text { myofibroblast senescence (Jun and } \\
\text { Lau, 2010) } \\
\text { In vivo acceleration of wound } \\
\text { closure by senescent cells through } \\
\text { induction of myofibroblast } \\
\text { differentiation through secretion of } \\
\text { PDGF-AA (Demaria et al, 2014; } \\
\text { Baker et a 2016) }\end{array}$ & $\begin{array}{l}\text { Senescence of activated stellate cells } \\
\text { limits liver fibrosis (Krizhanovsky et al, } \\
\text { 2008), mediated by CCN1 (Kim et al, } \\
\text { 2013) } \\
\text { CCN1-dependent senescence of } \\
\text { myofibroblasts limits myocardial fibrosis } \\
\text { (Meyer et al, 2016) } \\
\text { Senescent cells are found during natural } \\
\text { muscle repair in mouse (Le Roux et al, } \\
\text { 2015) } \\
\text { Exogenously-induced OIS favors skin } \\
\text { homeostasis in vivo and promotes tissue- } \\
\text { specific expression of stem cell markers } \\
\text { in skin and liver cells (Ritschka et al, } \\
\text { 2017); elimination of endogenous } \\
\text { senescent cells promotes hair-follicle } \\
\text { regeneration(Yosef et al, 2016) }\end{array}$ & $\begin{array}{l}\text { Senescent cells are recurrently } \\
\text { induced during salamander limb } \\
\text { regeneration, coinciding with the } \\
\text { generation of regenerative } \\
\text { progenitors, followed by their rapid } \\
\text { clearance (Yun et al, 2015) } \\
\quad \rightarrow \text { Function? }\end{array}$ \\
\hline
\end{tabular}

Senescent cells are found in various types of regenerative processes. During wound healing, cellular senescence contributes to the acceleration of wound closure and the alleviation of fibrosis via non cell-autonomous mechanisms. In tissue repair and homeostasis, senescent cells play positive roles through cell-autonomous prevention of fibrosis and have been proposed to promote cell plasticity upon injury. In regeneration, senescent cells are recurrently induced coinciding with the generation of regenerative progenitors, yet their functions remain unknown.

First, they suggest that cellular senescence is a non-essential but intrinsic part of vertebrate development. Second, they insinuate that the functions of senescent cells arose early in evolutionary terms and in connection with developmental processes, perhaps predating other forms of senescence. Lastly, they suggest that cell senescence could have been incorporated in the developmental programme at various time points during vertebrate evolution.

\section{An emerging player in responses to injury}

Interestingly, in the past few years evidence has started to emerge suggesting the participation of cellular senescence in responses to tissue injury (Table 1). Such responses usually involve distinctive types of regenerative phenomena which, according to the current view of the field, can be divided into three major processes: wound healing, tissue repair and regeneration (Galliot et al., 2017). Each of these are characterised by particular kinetics, triggers, molecular and cellular requirements, and can occur with different outcomes in different organisms. As concisely summarised by Galliot et al., wound healing entails the process of full or partial tissue restoration upon wounding and, in mammals, is often disrupted by fibrosis. Tissue repair refers to the restoration of an injured organ without exact patterning reconstruction, as in the case of liver, heart and muscle. In contrast, regeneration involves extensive regrowth and patterning of a complex structure, such as a part of an organ or a full appendage, and requires the generation and mobilisation of multiple cell type progenitors followed by their coordinated differentiation and spatial organisation (Galliot et al., 2017). To date, cellular senescence has been shown to contribute to wound healing and tissue repair. Furthermore, recent evidence has hinted at a potential role for senescence in regeneration of complex structures (Yun et al., 2015).

A critical aspect of wound healing is the maintenance of tissue integrity surrounding the wound, a process that relies on the deposition of extracellular matrix (ECM) and which should be tightly controlled, as it otherwise leads to fibrosis and scarring. Notably, cellular senescence is part of the mechanisms exerting such control, limiting fibrosis during wound healing (Jun and Lau, 2010). Following a phase of proliferation and ECM deposition, myofibroblasts at the wound site undergo senescence, which arrests their cell cycle and promotes expression of ECM degrading enzymes. Senescence is triggered by CCN1 (also known as CYR61), a matricellular protein dynamically expressed during wound healing. In vitro, CCN1 induces senescence through its interaction with integrins and heparan sulfate proteoglycans at the cell surface leading to the activation of NADPH oxidase 1 and ROS production, which then triggers $\mathrm{p} 53$ activation and $\mathrm{p} 16$ expression via the ERK and p38 MAPK pathways. In vivo, defects in CCN1 lead to lack of myofibroblast senescence at the wound site and exacerbate fibrosis, which can be reverted by topical application of purified CCN1, highlighting the importance of senescence as a fibrosis-limiting mechanism during wound healing (Jun and Lau, 2010).

The importance of senescence in fibrosis control is further supported by a more recent study, which uncovered additional functions of cell senescence in wound closure (Demaria et al., 2014). Using mice carrying a transgenic cassette for specific p16+ senescent cell labelling and elimination (p16-3MR), Demaria et al., described that senescent fibroblast and endothelial cells are transiently induced at wound sites, where they accelerate wound closure. This is likely due to the senescence-mediated induction of myofibroblast differentiation, dependent on the secretion of platelet-growth factor AA(PDGF-AA) by senescent cells. Elimination of senescent cells leads to moderate delays in wound healing, a decrease in myofibroblast appearance (as estimated by the marker smooth muscle actin), and alterations in granular tissue resulting in fibrosis. Importantly, topical treatment with PDGF-AA is able to revert the alterations in wound closure kinetics and the decrease in myofibroblasts, while it does not revert the fibrotic increase, suggesting that the latter depends on other factors, such as MMPs, secreted by senescent cells (Demaria et al., 2014). Of note, wound closure is completed at 12 days both in the presence or absence of senescent cells, suggesting that this function of cell senescence, much like in development, is either non-essential or redundant. Together, these studies revealed that cell senescence has positive functions in wound healing contexts. While the effect of persistent endogenous senescent cells was not addressed in this work, it is of note that chronic, non-healing wounds have been shown to contain cells with senescent traits (Vande Berg et al., 2005). It is therefore possible that injury-induced senescent cells have beneficial effects when transient, yet detrimental ones when permanent, such as the promotion of inflammation, leading to wound healing impairments. This is a recurrent concept when considering the physiological roles of senescent cells, and one that merits further investigation.

The beneficial side of senescence is also evident in the context of tissue repair following liver or heart injury. In the liver, chronic damage results in fibrosis, which can eventually progress towards cirrhosis. In murine models of chronic liver injury, activated hepatic stellate cells undergo cell proliferation and ECM deposition, forming a fibrotic scar (Kong et al., 2012, Krizhanovsky et al., 2008). Mir- 
roring the events during skin wound healing, these cells eventually undergo senescence and this limits their proliferation and promotes ECM degradation, thereby restricting the fibrotic response (Krizhanovsky et al., 2008). This is followed by the immune-mediated clearance of these cells, achieved through natural killer (NK cells), thus completing the cycle (Krizhanovsky et al., 2008). Mechanistically, hepatic stellate cell senescence is dependent on CCN1 for its induction, as seen in the skin. Interestingly, experiments using mice with hepatocyte-specific Ccn1 deletion revealed that CCN1induced senescent cells are not required for liver development or regeneration, but to inhibit fibrogenesis. Similar findings have been reported in contexts of myocardial fibrosis, where myofibroblasts were also found to undergo senescence dependent on CCN1 (Meyer et al., 2016). Cardiac-specific expression of CCN1 results in reduction of perivascular fibrosis, whereas genetic ablation of p53 and $\mathrm{p} 16$, which disrupts the myofibroblast senescent programme, leads to increased heart fibrosis (Meyer et al., 2016). Together, these findings establish CCN1-dependent cell senescence as a critical mechanism for the control of fibrosis.

A link between senescence and fibrosis is also found during muscle repair. In mice, inactivation of the endocytic adaptor Numb results in persistent p53-dependent senescence of myogenic cells following severe injury, leading to an in vivo decline in regenerative potential (Le Roux et al., 2015). Ex vivo experiments suggest that this decline could be explained by the generation of an inflammatory, pro-fibrotic environment caused by macrophage recruitment to senescent cells (Le Roux et al., 2015). Thus, this provides further support for the recurrent concept that persistent senescent cells can have detrimental effects, such as the exacerbation of fibrosis. Interestingly, this study also described the induction of a transient, non-myogenic senescent cell population following muscle injury. While the functions of this population were not characterised, this finding raised questions about their nature and impact on tissue repair.

Recently, two studies offered interesting insights into such questions by uncovering another facet of cellular senescence: its effect on cellular reprogramming. Using a 'reprogrammable' mice strain (expressing the Yamanaka factors OCT4, SOX2, KIf4 and c-MYC (OSKM) in an inducible fashion) which enables in vivo reprogramming of adult cells into induced-pluripotent cells (Abad et al., 2013), it was shown that various types of senescence, including senescence induced by bleomycin damage in the lung or snake venom cardiotoxin in the muscle, can enhance the efficiency of reprogramming in mice stimulated with OSKM (Chiche et al., 2017, Mosteiro et al., 2016). Efficiency of reprogramming is decreased in conditions which limit senescence, such as combined genetic deletion of 16 and ARF or treatment with the senolytic ABT-263, while conditions leading to the elevated presence of senescent cells (regardless of the type of senescence), such as palbociclib (a p16 functional mimetic) treatment, tissue damage, $\mathrm{X}$-irradiation and Ageing (Chiche et al., 2017, Mosteiro et al., 2016) increase it. The effect of senescent cells is likely mediated by the SASP, as disruption of NFkb abrogates the positive effect on reprogramming (Mosteiro et al., 2016). In particular, the secreted cytokine IL-6 has been proposed as a direct mediator of this effect, as treatment with anti-IL-6 antibodies decreases reprogramming efficiency while the opposite is observed upon recombinant IL-6 treatment in vivo (Chiche et al., 2017, Mosteiro et al., 2016), recapitulating prior observations in vitro (Brady et al., 2013). Although the re- programmable mouse is far from a normal in vivo system, these studies helped establish that cell senescence can be an inducer of cellular plasticity. This idea was also supported by a recent study showing that HRasV12-dependent oncogene-induced senescence, through the SASP, can lead to promotion of stem-cell markers in injury contexts such as skin and liver (Ritschka et al., 2017). Ritschka et al., showed that keratinocytes undergoing OIS acquire markers of somatic and cancer stem cells such as CD34, Lgr6 and Nestin, despite developing a senescent phenotype, both in vitro and in vivo. This depends on the SASP, as it is abrogated by NFkb inhibition. Furthermore, proliferating newborn primary mouse keratinocytes transiently exposed to OIS-derived condition media (2 days) ex vivo acquire skin stem cell markers and lead to increased hair follicle generation in a skin graft assay in vivo (Ritschka et al., 2017). Whether this represents an enhancement of stem-ness on keratinocytes that are not yet fully mature, or a de novo induction of stem-ness, needs further investigation. Yet, this work demonstrates that that OIS can stimulate cellular plasticity by promoting stem-ness. In addition, the authors went further and tested the effect of longer exposure to the OIS-derived SASP. In contrast to the effects after transient treatment, a 6-day exposure led to acquisition of senescence features in the mouse keratinocytes, which was suggested as an anti-tumourigenic response to counteract the promotion of stem-ness (Ritschka et al., 2017), although whether this occurs in physiological conditions remains to be determined.

Together, these three studies show that senescent cells can lead to the promotion of two types of cellular plasticity, reprogramming and stem-ness. Whether this is a mechanism whereby endogenous senescent cells, induced in a normal physiological injury context, could promote regeneration (as proposed in the aforementioned studies) remains unknown. Thus, it is still unclear if this aspect of senescence is physiologically relevant in a natural repair context and what its implications are. While these studies put forward the hypothesis that senescence-mediated induction of plasticity could contribute to tissue repair, it has also been shown that elimination of endogenous senescent cells in various contexts is beneficial for repair processes. For example, senolytic treatment leads to an increase in hair-follicle stem cell proliferation (Yosef et al., 2016), in disagreement with the aforementioned studies. Furthermore, senescent cells in Ageing contexts have been shown to promote cellular plasticity (Chiche et al., 2017, Mosteiro et al., 2016), yet they correlate with impaired regenerative responses to injury, which are improved upon senescent cell elimination (see previous section). Lastly, recent evidence from a model of Six1-induced senescence suggests that senescent cells can trigger a differentiation programme capable of limiting rather than promoting cellular plasticity (Adrados et al., 2016). Although these disparate observations could perhaps be explained by contextual differences, they underscore that much is yet to be learned concerning the impact of senescence-induced plasticity. In addition, the promotion of highly plastic states such as those achieved through reprogramming is tightly associated with teratoma and tumour development (Abad et al., 2013). This raises the possibility that the effect of senescence on cellular plasticity is another aspect of its pro-tumourigenic potential. Indeed, somatic cell reprogramming is emerging as a major process underlying generation of cancer stem cells (Friedmann-Morvinski and Verma, 2014). Therefore, defining to what extent endogenous senescent cells promote cellular plasticity, the type of plasticity they 
elicit, whether this requires a particular microenvironment or cellular partners, and the mechanisms that regulate this function in in vivo contexts, would be essential for understanding their physiological roles, both in injury responses and elsewhere.

\section{What about regeneration?}

The finding that cellular senescence has positive roles in wound healing and tissue repair suggest the possibility that it could also play a role in natural regeneration. Although this suggestion has not yet been addressed directly, studies in the salamander limb regeneration model have recently delivered significant insights. Salamander limb regeneration is a striking example of regeneration that involves a rapid response to injury followed by the formation of a blastema (a mound of regenerative progenitors for the regeneration process), and the set up of a morphogenetic programme that allows the reconstitution of the limb to the original size and pattern specifications (Yun et al., 2013). Notably, recent research (Yun et al., 2015) found that senescent cells are recurrently induced during intermediate stages of regeneration, coinciding with the period of generation and expansion of regenerative progenitors, and are subsequently eliminated by a highly effective mechanism of senescence immunesurveillance which depends on macrophages (Fig. 3). These findings have several implications. First, they uncovered a highly efficient mechanism of immune surveillance operating in both normal and regenerating tissues that correlates with a lack of age-related accumulation of senescent cell in salamanders, the study of which could deliver new approaches for the elimination of senescent cells for therapeutic applications. Second, they provided the first evidence of senescent cell induction during regeneration, and opened the door to analysing whether transient induction of cellular senescence contributes to regeneration. Indeed, the reported dynamics of transient induction of senescent cells during key stages of regeneration followed by their timely elimination suggest that these cells could play positive roles in this process. A strong SASP signature has been reported in blastemas coinciding with peak induction of senescent cells (Yun et al., 2015), raising the possibility that these cells have paracrine effects on the regenerate. Lastly, these findings have established the salamander as a model in which to study the effects of cellular senescence in natural regeneration. In this connection, it is of note that adult salamanders such as newts regenerate through the induction of a particular form of cellular plasticity, namely the tightly controlled dedifferentiation of mature differentiated tissues (Tanaka et al.,
2016), a regenerative mechanism whose preferential use could be responsible for their extreme resistance to tumourigenesis. Thus, they constitute a system in which to address the impact of senescent cells on dedifferentiation.

Integrating these observations with the current understanding of the functions of cell senescence in various contexts, it is possible to formulate a number of hypotheses for how senescence could contribute to regenerative responses (Fig. 4). The first one (a) consists of the direct promotion of regeneration via a SASP-mediated enhancement of the generation (though induction of dedifferentiation, stem-ness or other) or proliferation of regenerative progenitors, or the creation of a pro-regenerative tissue microenvironment (via ECM remodelling, metabolic reshaping, vascularisation). Alternatively (b), senescent cells could simply act by recruiting elements of the immune system, such as macrophages, T-cells and NK cells, which could then execute pro-regenerative functions. Components of the immune system have been shown to contribute to responses to injury in a wide range of contexts. In particular the macrophage, an essential cell type recruited to senescent cells, plays critical functions in wound healing (Lucas et al., 2010), muscle regeneration (Ruffell et al., 2009), neurogenesis (Kyritsis et al., 2012) and regeneration of structures such as the salamander limb (Godwin et al., 2013), the zebrafish fin (Petrie et al., 2014) and the mouse digit tip (Simkin et al., 2017), among others. Furthermore, phenotypic changes and even induced-senescence of the immune cells themselves following their recruitment should be considered. As mentioned, senescent cells can elicit changes in macrophage polarisation in certain contexts (Lujambio et al., 2013), which can affect their functionality. Also, senescent NK cells have been shown to promote vascular remodelling and angiogenesis (Rajagopalan and Long, 2012), something that could be of relevance to their functions in injury responses. Lastly, a final possibility (c) is that cellular senescence could simply serve as a population balancing mechanism, as observed during the development of the endolymphatic sac of the inner ear (Storer et al., 2013), leading to arrest and subsequent clearance of particular cells, controlling the proportions of certain populations versus others. These hypotheses consider the non cell-autonomous effects of senescent cells as mediated primarily by the molecules secreted to the environment. However, a recent study has shed light on an additional process, intercellular protein transfer, by which senescent cells can transfer molecular mediators to their neighbours via cytoplasmic bridges both in vivo and in vitro

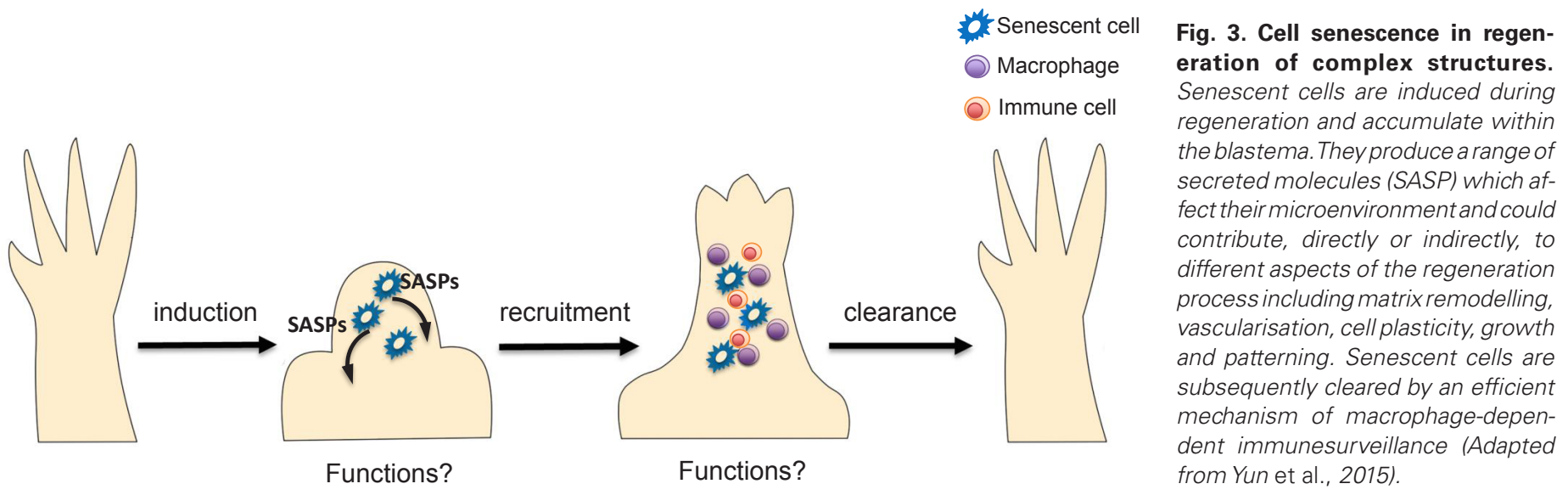


(Biran et al., 2015). This mechanism can mediate communication between senescent and epithelial and immune cells, and has been proposed to be relevant for senescent cell elimination (Biran et al., 2015). It is possible that this process is also important in the context of regenerative responses, by enabling the promotion of cell-to-cell transfer of molecular mediators between senescent and regenerative or supporting cells.

An important component of these hypotheses is the timely elimination of senescent cells, as their persistence could be detrimental for the regenerative process $(\mathrm{d})$. In pathological conditions or Ageing, senescent cells which persist through failures in clearance or increased/deregulated senescence induction rates leads to inflammation, niche disruption or, should it occur in progenitor cells, progenitor depletion (which explains the age-related decay seen in a number of systems), leading to regenerative impairments or tumour promotion. It is likely that the first two effects are mediated by the SASP. Through the course of a regenerative response, it is possible that the SASP evolves from a pro-regenerative to an anti-regenerative type; alternatively, perhaps the SASP does not change drastically but the functions of the SASP which could contribute to a regenerative process at one stage (e.g. promotion of cellular plasticity) become detrimental at a subsequent one. In both cases, senescent cell clearance would be required to avoid a pathological situation.

Together, these models highlight avenues for further research and at the same time underscore the current need for understanding the nature, role and regulation of cellular senescence in regenerative phenomena in the light of its potential biological and therapeutic importance.

\section{Future perspectives}

The impact of cellular senescence in physiological contexts, and in particular in responses to injury, is an exciting emerging area of research. As such, several important questions remain (Side Box). At the centre of these lies the molecular nature of senescent cells. Senescent cell populations are likely to be highly heterogeneous, with phenotypes that depend on the induction mode, cell type, time since induction and cellular interactions within the microenvironment. Given such heterogeneity, it is reasonable to ask if all cells
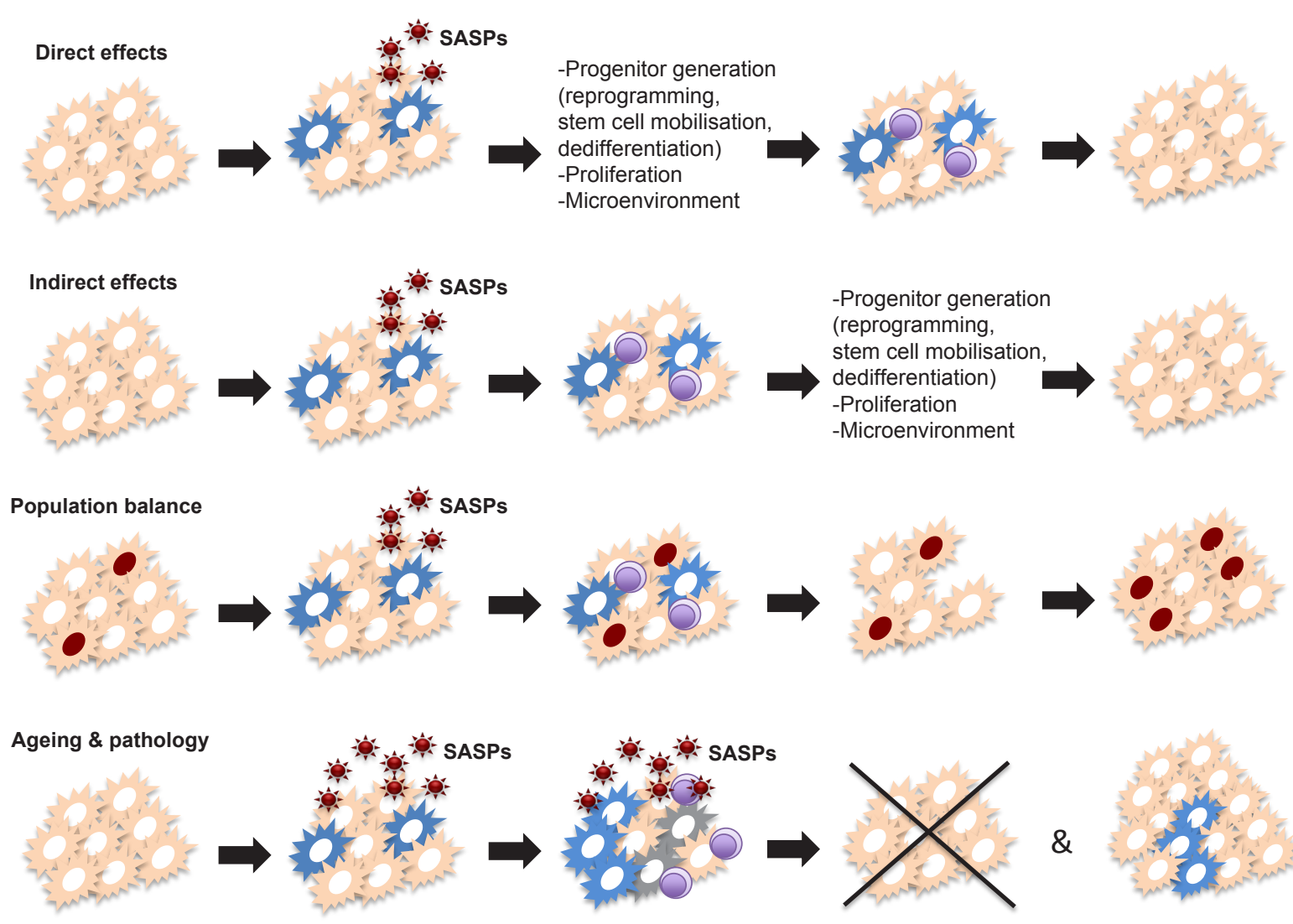

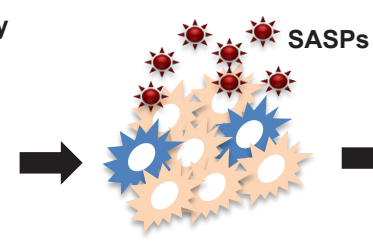

Senescent cell persistence (clearance impairment/ increased senescence)

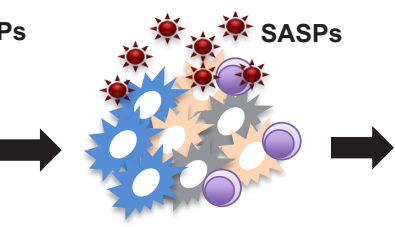

Persistent Inflammation Niche/systemic disruption Senescence of progenitor cells

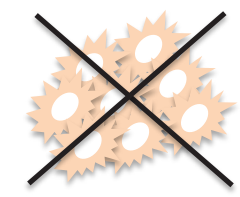

Impaired tissue repair and homeostasis

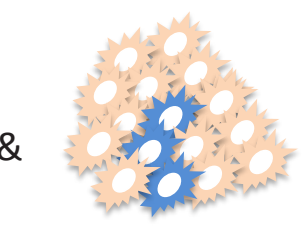

Tumourigenesis

Fig. 4. Hypotheses for the functions of senescent cells in regenerative processes. Transient senescent cells could promote tissue repair and regeneration directly (a) by enhancing the generation or proliferation of regenerative progenitors, or generating a pro-regenerative microenvironment through the SASP. Alternatively, they could exert these functions indirectly (b), via recruitment of immune cells which could themselves have pro-regenerative roles. Lastly, they could contribute to a population balancing mechanism (c), whereby senescence induction followed by clearance leads to the enhanced contribution of non-senescent cell populations to the final structure. Persistence of senescent cells and/or failure of senescence surveillance in ageing and/or pathological conditions (d), can lead to persistent inflammation, niche disruption or progenitor depletion, resulting in impaired regenerative responses and/or tumourigenesis. 


\section{Side box - Outstanding questions}

What is the level of heterogeneity -cell type composition, phenotype- among senescent cell populations?

To what extent does this impact on their phenotype and functions?

What are the common molecular denominators among different types of senescence?

How is senescence induced in physiological injury contexts - is it programmed and if so what are the triggers?

To what extent and by which mechanisms does cellular senescence impact diverse forms of cell plasticity? Is this pro-tumourigenic?

What is the effect of senescent cells in other cell populations in vivo?

Do senescent cells exert their functions directly or via engagement of other cell types (e.g. immune cells)?

How and by which mechanisms does the senescent phenotype evolve in time?

How and when does this phenotype become negative in injury contexts?

How is their elimination regulated? Are there general mechanisms or is it cell/context-dependent?

What are the effectors and signals mediating senescence clearance in vivo?

within a particular population could trigger a particular effect, or only a proportion. Furthermore, it is not yet clear how senescent cells are induced in vivo, how does the SASP evolves in time, if/ when it acquires negative traits and how their clearance is regulated in physiological contexts. With regards to their effects on regenerative responses, the recent findings that cell senescence could contribute to the modulation of certain types of cell plasticity are exciting. However, it is not yet clear if this is an important mechanism by which endogenous senescent cells contribute to responses to tissue injury. There are different types of cell plasticity (pluripotency, stem-ness and controlled dedifferentiation) which are mechanistically very different processes, with particular requirements and equally diverse physiological effects. Thus, it would be important to determine to what extent senescent cells impact on cellular plasticity in various physiological contexts. Addressing these issues may underscore potential targets for therapeutic applications and offer a framework for the development of strategies for the treatment or prevention of pathological conditions.

With regards to therapeutic applications, the finding that senescent cells have beneficial functions in contexts of tissue injury is highly significant. First, the identification of molecular mediators of such functions, likely SASP-associated molecules, could provide therapeutic targets for pro-regenerative interventions. Second, in light of the recent development of senolytic strategies, recent findings will guide such approaches so that the negative effects of senescence (e.g. promotion of an age-related pathology) are suppressed, while maintaining the positive effects (e.g. wound healing or fibrosis limitation). This may imply the use of senolytic treatments conditioned by space and time or the design of combined therapies, accompanied by a thorough consideration of the physiological costs and benefits of every therapeutic intervention.

\section{Acknowledgements}

The author would like to thank Ivan Mikicic and Qinghao Yu for critical reading and suggestions.

\section{References}

ABAD, M., MOSTEIRO, L., PANTOJA, C., CANAMERO, M., RAYON, T., ORS, I., GRANA, O., MEGIAS, D., DOMINGUEZ, O., MARTINEZ, D. et al., (2013). Reprogramming in vivo produces teratomas and iPS cells with totipotency features. Nature 502: 340-345.

ACOSTA, J.C., BANITO, A., WUESTEFELD, T., GEORGILIS, A., JANICH, P., MORTON, J.P., ATHINEOS, D., KANG, T.W., LASITSCHKA, F., ANDRULIS, M. et al., (2013). A complex secretory program orchestrated by the inflammasome controls paracrine senescence. Nat Cell Biol 15: 978-990.

AcostA, J.C., O'LOGHLEN, A., BANITO, A., GUIJARRO, M.V., AUGERT, A., RAGUZ, S., FUMAGALLI, M., DA COSTA, M., BROWN, C., POPOV, N. et al., (2008). Chemokine signaling via the CXCR2 receptor reinforces senescence. Cell 133: 1006-1018.

ADRADOS, I., LARRASA-ALONSO, J., GALARRETA, A., LOPEZ-ANTONA, I., MENENDEZ, C., ABAD, M., GIL, J., MORENO-BUENO, G. and PALMERO, I. (2016). The homeoprotein SIX1 controls cellular senescence through the regulation of p16INK4A and differentiation-related genes. Oncogene 35: 3485-3494.

ALIMONTI, A., NARDELLA, C., CHEN, Z., CLOHESSY, J.G., CARRACEDO, A., TROTMAN, L.C., CHENG, K., VARMEH, S., KOZMA, S.C., THOMAS, G. et al., (2010). A novel type of cellular senescence that can be enhanced in mouse models and human tumor xenografts to suppress prostate tumorigenesis. J Clin Invest 120: 681-693.

BAKER, D.J., CHILDS, B.G., DURIK, M., WIJERS, M.E., SIEBEN, C.J., ZHONG, J., SALTNESS, R.A., JEGANATHAN, K.B., VERZOSA, G.C., PEZESHKI, A. et al., (2016). Naturally occurring p16(Ink4a)-positive cells shorten healthy lifespan. Nature 530: 184-189.

BAKER, D.J., WIJSHAKE, T., TCHKONIA, T., LEBRASSEUR, N.K., CHILDS, B.G. VAN DE SLUIS, B., KIRKLAND, J.L. and VAN DEURSEN, J.M. (2011). Clearance of p16Ink4a-positive senescent cells delays ageing-associated disorders. Nature 479: 232-236.

BAUS, F., GIRE, V., FISHER, D., PIETTE, J. and DULIC, V. (2003). Permanent cell cycle exit in G2 phase after DNA damage in normal human fibroblasts. EMBO J 22: 3992-4002.

BIRAN, A., PERELMUTTER, M., GAL, H., BURTON, D.G., OVADYA, Y., VADAI, E., GEIGER, T. and KRIZHANOVSKY, V. (2015). Senescent cells communicate via intercellular protein transfer. Genes Dev 29: 791-802.

BRADY, J.J., LI, M., SUTHRAM, S., JIANG, H., WONG, W.H. and BLAU, H.M. (2013) Early role for IL-6 signalling during generation of induced pluripotent stem cells revealed by heterokaryon RNA-Seq. Nat Cell Biol 15: 1244-1252.

BRAiG, M., LEE, S., LODDENKEMPER, C., RUDOLPH, C., PETERS, A.H., SCHLEGELBERGER, B., STEIN, H., DORKEN, B., JENUWEIN, T. and SCHMITT, C.A. (2005). Oncogene-induced senescence as an initial barrier in lymphoma development. Nature 436: 660-665.

BRAUMULLER, H., WIEDER, T., BRENNER, E., ASSMANN, S., HAHN, M., ALKHALED, M., SCHILBACH, K., ESSMANN, F., KNEILLING, M., GRIESSINGER, C. et al., (2013). T-helper-1-cell cytokines drive cancer into senescence. Nature 494: 361-365.

BRAUN, H., SCHMIDT, B.M., RAISS, M., BAISANTRY, A., MIRCEA-CONSTANTIN, D., WANG, S., GROSS, M.L., SERRANO, M., SCHMITT, R. and MELK, A. (2012). Cellular senescence limits regenerative capacity and allograft survival. JAm Soc Nephrol 23: 1467-1473.

BURD, C.E., SORRENTINO, J.A., CLARK, K.S., DARR, D.B., KRISHNAMURTHY, J., DEAL, A.M., BARDEESY, N., CASTRILLON, D.H., BEACH, D.H. and SHARPLESS, N.E. (2013). Monitoring tumorigenesis and senescence in vivo with a p16(INK4a)luciferase model. Cell 152: 340-351.

BURKHART, D.L. and SAGE, J. (2008). Cellular mechanisms of tumour suppression by the retinoblastoma gene. Nat Rev Cancer 8: 671-682.

BURTON, D.G. and KRIZHANOVSKY, V. (2014). Physiological and pathological consequences of cellular senescence. Cell Mol Life Sci 71: 4373-4386. 
CAMPISI, J. (2005). Senescent cells, tumor suppression, and organismal aging: good citizens, bad neighbors. Cell 120: 513-522.

CAMPISI, J. (2013). Aging, cellular senescence, and cancer. Annu Rev Physiol 75: 685-705.

CANINO, C., MORI, F., CAMBRIA, A., DIAMANTINI, A., GERMONI, S., ALESSANDRINI, G., BORSELLINO, G., GALATI, R., BATTISTINI, L., BLANDINO, R. et al., (2012). SASP mediates chemoresistance and tumor-initiating-activity of mesothelioma cells. Oncogene 31: 3148-3163.

CHANDRA, T. and NARITA, M. (2013). High-order chromatin structure and the epigenome in SAHFs. Nucleus 4: 23-28.

CHANG, J., WANG, Y., SHAO, L., LABERGE, R.M., DEMARIA, M., CAMPISI, J. JANAKIRAMAN, K., SHARPLESS, N.E., DING, S., FENG, W. et al., (2016). Clearance of senescent cells by ABT263 rejuvenates aged hematopoietic stem cells in mice. Nat Med 22: 78-83.

CHICHE, A., LE ROUX, I., VON JOEST, M., SAKAI, H., AGUIN, S.B., CAZIN, C., SALAM, R., FIETTE, L., ALEGRIA, O., FLAMANT, P. et al., (2017). Injury-Induced Senescence Enables In vivo Reprogramming in Skeletal Muscle. Cell Stem Cell 20: 407-414 e4

CHILDS, B.G., BAKER, D.J., WIJSHAKE, T., CONOVER, C.A., CAMPISI, J. and VAN DEURSEN, J.M. (2016). Senescent intimal foam cells are deleterious at all stages of atherosclerosis. Science 354: 472-477.

CHUPRIN, A., GAL, H., BIRON-SHENTAL, T., BIRAN, A., AMIEL, A., ROZENBLATT, S. and KRIZHANOVSKY, V. (2013). Cell fusion induced by ERVWE1 or measles virus causes cellular senescence. Genes Dev 27: 2356-66.

COLLINS, C.J. and SEDIVY, J.M. (2003). Involvement of the INK4a/Arf gene locus in senescence. Aging Cell 2: 145-150.

COPPE, J.P., PATIL, C.K., RODIER, F., KRTOLICA, A., BEAUSEJOUR, C.M., PARRINELLO, S., HODGSON, J.G., CHIN, K., DESPREZ, P.Y. and CAMPISI, J. (2010). Ahuman-like senescence-associated secretory phenotype is conserved in mouse cells dependent on physiological oxygen. PLoS One 5: e9188.

COPPE, J.P., PATIL, C.K., RODIER, F., SUN, Y., MUNOZ, D.P., GOLDSTEIN, J., NELSON, P.S., DESPREZ, P.Y. and CAMPISI, J. (2008). Senescence-associated secretory phenotypes reveal cell-nonautonomous functions of oncogenic RAS and the p53 tumor suppressor. PLoS Biol 6: 2853-2868.

COSGROVE, B.D., GILBERT, P.M., PORPIGLIA, E., MOURKIOTI, F., LEE, S.P., CORBEL, S.Y., LLEWELLYN, M.E., DELP, S.L. and BLAU, H.M. (2014). Rejuvenation of the muscle stem cell population restores strength to injured aged muscles. Nat Med 20: 255-264

D'ADDADIFAGAGNA, F., REAPER, P.M., CLAY-FARRACE, L., FIEGLER, H., CARR, P., VON ZGLINICKI, T., SARETZKI, G., CARTER, N.P. and JACKSON, S.P. (2003). A DNA damage checkpoint response in telomere-initiated senescence. Nature 426: 194-198.

DAVAAPIL, H., BROCKES, J.P. and YUN, M.H. (2017). Conserved and nove functions of programmed cellular senescence during vertebrate development. Development 144: 106-114

DEMARIA, M., OHTANI, N., YOUSSEF, S.A., RODIER, F., TOUSSAINT, W., MITCHELL, J.R., LABERGE, R.M., VIJG, J., VAN STEEG, H., DOLLE, M.E. et al., (2014). An essential role for senescent cells in optimal wound healing through secretion of PDGF-AA. Dev Cell 31: 722-733.

DIMRI, G.P., LEE, X.H., BASILE, G., ACOSTA, M., SCOTT, C., ROSKELLEY, C., MEDRANO, E.E., LINSKENS, M., RUBELJ, I., PEREIRASMITH, O. et al., (1995). A Biomarker That Identifies Senescent Human-Cells in Culture and in Aging Skin in-Vivo. Proc. Natl. Acad. Sci. USA 92: 9363-9367.

DOU, Z., IVANOV, A., ADAMS, P.D. and BERGER, S.L. (2016). Mammalian autophagy degrades nuclear constituents in response to tumorigenic stress. Autophagy 12 1416-1417.

EVANGELOU, K., LOUGIAKIS, N., RIZOU, S.V., KOTSINAS, A., KLETSAS, D., MUNOZ-ESPIN, D., KASTRINAKIS, N.G., POULI, N., MARAKOS, P., TOWNSEND, P. et al., (2017). Robust, universal biomarker assay to detect senescent cells in biological specimens. Aging Cell 16: 192-197

FRIEDMANN-MORVINSKI, D. and VERMA, I.M. (2014). Dedifferentiation and reprogramming: origins of cancer stem cells. EMBO Rep 15: 244-253.

GALLIOT, B., CRESCENZI, M., JACINTO, A. and TAJBAKHSH, S. (2017). Trends in tissue repair and regeneration. Development 144: 357-364.

GARCIA-PRAT, L., MARTINEZ-VICENTE, M., PERDIGUERO, E., ORTET, L., RODRIGUEZ-UBREVA, J., REBOLLO, E., RUIZ-BONILLA, V., GUTARRA, S.,
BALLESTAR, E., SERRANO, A.L. et al., (2016). Autophagy maintains stemness by preventing senescence. Nature 529: 37-42.

GIRE, V. and DULIC, V. (2015). Senescence from G2 arrest, revisited. Cell Cycle 14: $297-304$

GODWIN, J.W., PINTO, A.R. and ROSENTHAL, N.A. (2013). Macrophages are required for adult salamander limb regeneration. Proc Natl Acad Sci USA 110: 9415-9420.

HAYFLICK, L. (1965). The Limited in vitro Lifetime of Human Diploid Cell Strains. Exp Cell Res 37: 614-636.

HAYFLICK, L. and MOORHEAD, P.S. (1961). The serial cultivation of human diploid cell strains. Exp Cell Res 25: 585-621.

HELMAN, A., KLOCHENDLER, A., AZAZMEH, N., GABAI, Y., HORWITZ, E., ANZI, S. SWISA, A., CONDIOTTI, R., GRANIT, R.Z., NEVO, Y. et al., (2016). p16(Ink4a)induced senescence of pancreatic beta cells enhances insulin secretion. Na Med 22: 412-420.

HERBIG, U., JOBLING, W.A., CHEN, B.P., CHEN, D.J. and SEDIVY, J.M. (2004) Telomere shortening triggers senescence of human cells through a pathway involving ATM, p53, and p21(CIP1), but not p16(INK4a). Mol Cell 14: 501-513.

HOARE, M., ITO, Y., KANG, T.W., WEEKES, M.P., MATHESON, N.J., PATTEN, D.A., SHETTY, S., PARRY, A.J., MENON, S., SALAMA, R. et al., (2016). NOTCH1 mediates a switch between two distinct secretomes during senescence. Nat Cell Biol 18: 979-992.

HOENICKE, L. and ZENDER, L. (2012). Immune surveillance of senescent cells-biological significance in cancer- and non-cancer pathologies. Carcinogenesis 33: $1123-1126$

HUBACKOVA, S., KREJCIKOVA, K., BARTEK, J. and HODNY, Z. (2012). IL1- and TGFbeta-Nox4 signaling, oxidative stress and DNA damage response are shared feature of replicative, oncogene-induced, and drug-induced paracrine 'bystander senescence'. Aging (Albany NY) 4: 932-951.

ITO, Y., HOARE, M. and NARITA, M. (2017). Spatial and Temporal Control of Senescence. Trends Cell Biol 27: 820-832.

JANZEN, V., FORKERT, R., FLEMING, H.E., SAITO, Y., WARING, M.T., DOMBKOWSKI, D.M., CHENG, T., DEPINHO, R.A., SHARPLESS, N.E. and SCADDEN D.T. (2006). Stem-cell ageing modified by the cyclin-dependent kinase inhibitor p16INK4a. Nature 443: 421-426.

JEON, O.H., KIM, C., LABERGE, R.M., DEMARIA, M., RATHOD, S., VASSEROT, A.P., CHUNG, J.W., KIM, D.H., POON, Y., DAVID, N. et al., (2017). Local clearance of senescent cells attenuates the development of post-traumatic osteoarthritis and creates a pro-regenerative environment. Nat Med 23: 775-781.

JOHMURA, Y., SHIMADA, M., MISAKI, T., NAIKI-ITO, A., MIYOSHI, H., MOTOYAMA N., OHTANI, N., HARA, E., NAKAMURA, M., MORITA, A. et al., (2014). Necessary and sufficient role for a mitosis skip in senescence induction. Mol Cell 55: 73-84

JUN, J.I. and LAU, L.F. (2010). The matricellular protein CCN1 induces fibroblast senescence and restricts fibrosis in cutaneous wound healing. Nat Cell Biol 12 676-685

KAMIJO, T., WEBER, J.D., ZAMBETTI, G., ZINDY, F., ROUSSEL, M.F. and SHERR C.J. (1998). Functional and physical interactions of the ARF tumor suppressor with p53 and Mdm2. Proc Natl Acad Sci USA 95: 8292-8297.

KANG, C. and ELLEDGE, S.J. (2016). How autophagy both activates and inhibits cellular senescence. Autophagy 12: 898-899.

KANG, C., XU, Q., MARTIN, T.D., LI, M.Z., DEMARIA, M., ARON, L., LU, T., YANKNER B.A., CAMPISI, J. and ELLEDGE, S.J. (2015). The DNAdamage response induces inflammation and senescence by inhibiting autophagy of GATA4. Science 349 aaa5612 - doi: 10.1126/science.aaa5612.

KANG, T.W., YEVSA, T., WOLLER, N., HOENICKE, L., WUESTEFELD, T., DAUCH, D., HOHMEYER, A., GEREKE, M., RUDALSKA, R., POTAPOVA, A. et al., (2011). Senescence surveillance of pre-malignant hepatocytes limits liver cancer development. Nature 479: 547-551.

KONG, X., FENG, D., WANG, H., HONG, F., BERTOLA, A., WANG, F.S. and GAO B. (2012). Interleukin-22 induces hepatic stellate cell senescence and restricts liver fibrosis in mice. Hepatology 56: 1150-1159.

KRIMPENFORT, P., IJPENBERG, A., SONG, J.Y., VAN DER VALK, M., NAWIJN, M., ZEVENHOVEN, J. and BERNS, A. (2007). p15Ink4b is a critical tumour suppressor in the absence of p16Ink4a. Nature 448: 943-946.

KRISHNAMURTHY, J., RAMSEY, M.R., LIGON, K.L., TORRICE, C., KOH, A., BONNERWEIR, S. and SHARPLESS, N.E. (2006). p16INK4a induces an age-dependent decline in islet regenerative potential. Nature 443: 453-457 
KRIZHANOVSKY, V., YON, M., DICKINS, R.A., HEARN, S., SIMON, J., MIETHING, C., YEE, H., ZENDER, L. and LOWE, S.W. (2008). Senescence of activated stellate cells limits liver fibrosis. Cell 134: 657-667.

KRTOLICA, A., PARRINELLO, S., LOCKETT, S., DESPREZ, P.Y. and CAMPISI, J. (2001). Senescent fibroblasts promote epithelial cell growth and tumorigenesis: a link between cancer and aging. Proc Natl Acad Sci USA 98: 12072-12077.

KUILMAN, T., MICHALOGLOU, C., MOOI, W.J. and PEEPER, D.S. (2010). The essence of senescence. Genes Dev 24: 2463-2479.

KUILMAN, T., MICHALOGLOU, C., VREDEVELD, L.C., DOUMA, S., VAN DOORN, R., DESMET, C.J., AARDEN, L.A., MOOI, W.J. and PEEPER, D.S. (2008). Oncogene-induced senescence relayed by an interleukin-dependent inflammatory network. Cell 133: 1019-1031.

KYRITSIS, N., KIZIL, C., ZOCHER, S., KROEHNE, V., KASLIN, J., FREUDENREICH, D., ILTZSCHE, A. and BRAND, M. (2012). Acute inflammation initiates the regenerative response in the adult zebrafish brain. Science 338: 1353-1356.

LABERGE, R.M., AWAD, P., CAMPISI, J. and DESPREZ, P.Y. (2012). Epithelialmesenchymal transition induced by senescent fibroblasts. Cancer Microenviron 5: 39-44.

LE ROUX, I., KONGE, J., LE CAM, L., FLAMANT, P. and TAJBAKHSH, S. (2015). Numb is required to prevent $\mathrm{p} 53$-dependent senescence following skeletal muscle injury. Nat Commun 6: 8528.

LEE, B.Y., HAN, J.A., IM, J.S., MORRONE, A., JOHUNG, K., GOODWIN, E.C., KLEIJER, W.J., DIMAIO, D. and HWANG, E.S. (2006). Senescence-associated beta-galactosidase is lysosomal beta-galactosidase. Aging Cell 5: 187-195.

LI, H., LIU, P., XU, S., LI, Y., DEKKER, J.D., LI, B., FAN, Y., ZHANG, Z., HONG, Y., YANG, G. et al., (2017). FOXP1 controls mesenchymal stem cell commitment and senescence during skeletal aging. J Clin Invest 127: 1241-1253.

LIN, A.W., BARRADAS, M., STONE, J.C., VANAELST, L., SERRANO, M. and LOWE, S.W. (1998). Premature senescence involving $\mathrm{p} 53$ and $\mathrm{p} 16$ is activated in response to constitutive MEK/MAPK mitogenic signaling. Genes Dev 12: 3008-3019.

LIU, D. and HORNSBY, P.J. (2007). Senescent human fibroblasts increase the early growth of xenograft tumors via matrix metalloproteinase secretion. Cancer Res 67: 3117-3126.

LUCAS, T., WAISMAN, A., RANJAN, R., ROES, J., KRIEG, T., MULLER, W., ROERS, A. and EMING, S.A. (2010). Differential roles of macrophages in diverse phases of skin repair. J Immunol 184: 3964-3977.

LUJAMBIO, A., AKKARI, L., SIMON, J., GRACE, D., TSCHAHARGANEH, D.F., BOLDEN, J.E., ZHAO, Z., THAPAR, V., JOYCE, J.A., KRIZHANOVSKY, V. et al., (2013). Non-cell-autonomous tumor suppression by p53. Cell 153: 449-460.

MARCOTTE, R., LACELLE, C. and WANG, E. (2004). Senescent fibroblasts resist apoptosis by downregulating caspase-3. Mech Ageing Dev 125: 777-783.

MEYER, K., HODWIN, B., RAMANUJAM, D., ENGELHARDT, S. and SARIKAS, A. (2016). Essential Role for Premature Senescence of Myofibroblasts in Myocardial Fibrosis. J Am Coll Cardiol 67: 2018-2028.

MOLOFSKY, A.V., SLUTSKY, S.G., JOSEPH, N.M., HE, S., PARDAL, R., KRISHNAMURTHY, J., SHARPLESS, N.E. and MORRISON, S.J. (2006). Increasing p16INK4a expression decreases forebrain progenitors and neurogenesis during ageing. Nature 443: 448-452

MOSTEIRO, L., PANTOJA, C., ALCAZAR, N., MARION, R.M., CHONDRONASIOU, D., ROVIRA, M., FERNANDEZ-MARCOS, P.J., MUNOZ-MARTIN, M., BLANCOAPARICIO, C., PASTOR, J. et al., (2016). Tissue damage and senescence provide critical signals for cellular reprogramming in vivo. Science 354: aaf4445.

MUNOZ-ESPIN, D., CANAMERO, M., MARAVER,A., GOMEZ-LOPEZ, G., CONTRERAS, J., MURILLO-CUESTA, S., RODRIGUEZ-BAEZA, A., VARELA-NIETO, I., RUBERTE, J., COLLADO, M. et al., (2013). Programmed cell senescence during mammalian embryonic development. Cell 155: 1104-1118.

NACHER, V., CARRETERO, A., NAVARRO, M., ARMENGOL, C., LLOMBART, C., RODRIGUEZ, A., HERRERO-FRESNEDA, I., AYUSO, E. and RUBERTE, J. (2006). The quail mesonephros: a new model for renal senescence? J Vasc Res 43: 581-586.

NELSON, G., WORDSWORTH, J., WANG, C., JURK, D., LAWLESS, C., MARTINRUIZ, C. and VON ZGLINICKI, T. (2012). A senescent cell bystander effect: senescence-induced senescence. Aging Cell 11: 345-349.

PETRIE, T.A., STRAND, N.S., YANG, C.T., RABINOWITZ, J.S. and MOON, R.T. (2014). Macrophages modulate adult zebrafish tail fin regeneration. Development 141: 2581-2591.
RAI, T.S. and ADAMS, P.D. (2013). Lessons from senescence: chromatin maintenance in non-proliferating cells. Biochim Biophys Acta 1819: 322-331.

RAJAGOPALAN, S. and LONG, E.O. (2012). Cellular senescence induced by CD158d reprograms natural killer cells to promote vascular remodeling. Proc Natl Acad Sci USA 109: 20596-20601.

RITSCHKA, B., STORER, M., MAS, A., HEINZMANN, F., ORTELLS, M.C., MORTON, J.P., SANSOM, O.J., ZENDER, L. and KEYES, W.M. (2017). The senescenceassociated secretory phenotype induces cellular plasticity and tissue regeneration. Genes Dev 31: 172-183.

RODIER, F. and CAMPISI, J. (2011). Four faces of cellular senescence. J Cell Biol 192: 547-556.

RODIER, F., MUNOZ, D.P., TEACHENOR, R., CHU, V., LE, O., BHAUMIK, D., COPPE, J.P., CAMPEAU, E., BEAUSEJOUR, C.M., KIM, S.H. et al., (2011). DNA-SCARS: distinct nuclear structures that sustain damage-induced senescence growth arrest and inflammatory cytokine secretion. J Cell Sci 124: 68-81.

RUFFELL, D., MOURKIOTI, F., GAMBARDELLA, A., KIRSTETTER, P., LOPEZ, R.G., ROSENTHAL, N. and NERLOV, C. (2009). A CREB-C/EBPbeta cascade induces M2 macrophage-specific gene expression and promotes muscle injury repair. Proc Natl Acad Sci USA 106: 17475-17480.

SADAIE, M., SALAMA, R., CARROLL, T., TOMIMATSU, K., CHANDRA, T., YOUNG, A.R., NARITA, M., PEREZ-MANCERA, P.A., BENNETT, D.C., CHONG, H. et al., (2013). Redistribution of the Lamin B1 genomic binding profile affects rearrangement of heterochromatic domains and SAHF formation during senescence. Genes Dev 27: 1800-1808.

SAGIV, A. and KRIZHANOVSKY, V. (2013). Immunosurveillance of senescent cells: the bright side of the senescence program. Biogerontology 14: 617-628.

SCHAFER, M.J., WHITE, T.A., IIJIMA, K., HAAK, A.J., LIGRESTI, G., ATKINSON E.J., OBERG, A.L., BIRCH, J., SALMONOWICZ, H., ZHU, Y. et al., (2017). Cellular senescence mediates fibrotic pulmonary disease. Nat Commun 8: 14532.

SELUANOV, A., GORBUNOVA, V., FALCOVITZ, A., SIGAL, A., MILYAVSKY, M., ZURER, I., SHOHAT, G., GOLDFINGER, N. and ROTTER, V. (2001). Change of the death pathway in senescent human fibroblasts in response to DNA damage is caused by an inability to stabilize p53. Mol Cell Biol 21: 1552-1564.

SERRANO, M., LIN, A.W., MCCURRACH, M.E., BEACH, D. and LOWE, S.W. (1997) Oncogenic ras provokes premature cell senescence associated with accumulation of p53 and p16INK4a. Cell 88: 593-602.

SHARPLESS, N.E. and SHERR, C.J. (2015). Forging a signature of in vivo senescence. Nat Rev Cancer 15: 397-408.

SHAY, J.W., PEREIRA-SMITH, O.M. and WRIGHT, W.E. (1991). A role for both RB and p53 in the regulation of human cellular senescence. Exp Cell Res 196: 33-39.

SHIMI, T., BUTIN-ISRAELI, V., ADAM, S.A., HAMANAKA, R.B., GOLDMAN, A.E., LUCAS, C.A., SHUMAKER, D.K., KOSAK, S.T., CHANDEL, N.S. and GOLDMAN, R.D. (2011). The role of nuclear lamin B1 in cell proliferation and senescence. Genes Dev 25: 2579-2593

SIMKIN, J., SAMMARCO, M.C., MARRERO, L., DAWSON, L.A., YAN, M., TUCKER, C., CAMMACK, A. and MUNEOKA, K. (2017). Macrophages are required to coordinate mouse digit tip regeneration. Development 144: 3907-3916.

SOUSA-VICTOR, P., GUTARRA, S., GARCIA-PRAT, L., RODRIGUEZ-UBREVA J., ORTET, L., RUIZ-BONILLA, V., JARDI, M., BALLESTAR, E., GONZALEZ, S., SERRANO, A.L. et al., (2014). Geriatric muscle stem cells switch reversible quiescence into senescence. Nature 506: 316-321.

STEIN, G.H., BEESON, M. and GORDON, L. (1990). Failure to phosphorylate the retinoblastomagene product in senescenthuman fibroblasts. Science249:666-669.

STORER, M., MAS, A., ROBERT-MORENO, A., PECORARO, M., ORTELLS, M.C., DI GIACOMO, V., YOSEF, R., PILPEL, N., KRIZHANOVSKY, V., SHARPE, J. et al., (2013). Senescence is a developmental mechanism that contributes to embryonic growth and patterning. Cell 155: 1119-1130.

TANAKA, H.V., NG, N.C., YANG YU, Z., CASCO-ROBLES, M.M., MARUO, F., TSONIS, P.A. and CHIBA, C. (2016). A developmentally regulated switch from stem cells to dedifferentiation for limb muscle regeneration in newts. Nat Commun 7: 11069.

VANDEURSEN, J.M. (2014). The role of senescent cells in ageing. Nature 509:439-46

VANDE BERG, J.S., ROSE, M.A., HAYWOOD-REID, P.L., RUDOLPH, R., PAYNE, W.G. and ROBSON, M.C. (2005). Cultured pressure ulcer fibroblasts show replicative senescence with elevated production of plasmin, plasminogen activator inhibitor-1, and transforming growth factor-beta1. Wound Repair Regen 13: 76-83. 


\section{M.H.Yun}

VILLIARD, E., DENIS, J.F., HASHEMI, F.S., IGELMANN, S., FERBEYRE, G. and ROY, S. (2017). Senescence gives insights into the morphogenetic evolution of anamniotes. Biol Open 6: 891-896.

WANG, C., JURK, D., MADDICK, M., NELSON, G., MARTIN-RUIZ, C. and VON ZGLINICKI, T. (2009). DNA damage response and cellular senescence in tissues of aging mice. Aging Cell 8: 311-323.

WANG, E. (1995). Senescent human fibroblasts resist programmed cell death, and failure to suppress bcl2 is involved. Cancer Res 55: 2284-2292.

XU, M., PALMER, A.K., DING, H., WEIVODA, M.M., PIRTSKHALAVA, T., WHITE, T.A., SEPE, A., JOHNSON, K.O., STOUT, M.B., GIORGADZE, N. et al., (2015). Targeting senescent cells enhances adipogenesis and metabolic function in old age. eLife 4: e12997.

XUE, W., ZENDER, L., MIETHING, C., DICKINS, R.A., HERNANDO, E., KRIZHANOVSKY, V., CORDON-CARDO, C. and LOWE, S.W. (2007). Senescence and tumour clearance is triggered by p53 restoration in murine liver carcinomas. Nature 445: 656-660.

YANG, H. and FOGO, A.B. (2010). Cell senescence in the aging kidney. J Am Soc Nephrol 21: 1436-1439.

YOSEF, R., PILPEL, N., TOKARSKY-AMIEL, R., BIRAN, A., OVADYA, Y., COHEN,
S., VADAI, E., DASSA, L., SHAHAR, E., CONDIOTTI, R. et al., (2016). Directed elimination of senescent cells by inhibition of BCL-W and BCL-XL. Nat Commun 7: 11190

YOUNG, A.R., NARITA, M., FERREIRA, M., KIRSCHNER, K., SADAIE, M., DAROT, J.F., TAVARE, S., ARAKAWA, S., SHIMIZU, S., WATT, F.M. et al., (2009). Autophagy mediates the mitotic senescence transition. Genes Dev 23: 798-803.

YU, Q., KATLINSKAYA, Y.V., CARBONE, C.J., ZHAO, B., KATLINSKI, K. V., ZHENG, H., GUHA, M., LI, N., CHEN, Q., YANG, T. et al., (2015). DNA-damage-induced type I interferon promotes senescence and inhibits stem cell function. Cell Rep 11: 785-797.

YUN, M.H. (2015). Changes in Regenerative Capacity through Lifespan. Int J Mol Sci 16: 25392-25432.

YUN, M.H., DAVAAPIL, H. and BROCKES, J.P. (2015). Recurrent turnover of senescent cells during regeneration of a complex structure. eLife 4

YUN, M.H., GATES, P.B. and BROCKES, J.P. (2013). Regulation of p53 is critical for vertebrate limb regeneration. Proc Natl Acad Sci USA 110: 17392-17397.

ZHU, J., WOODS, D., MCMAHON, M. and BISHOP, J.M. (1998). Senescence of human fibroblasts induced by oncogenic Raf. Genes Dev 12: 2997-3007. 


\section{Further Related Reading, published previously in the Int. J. Dev. Biol.}

Cell-free Xenopus egg extracts for studying DNA damage response pathways

Steven Cupello, Christine Richardson and Shan Yan

Int. J. Dev. Biol. (2016) 60: 229-236

https://doi.org/10.1387/ijdb.160113sy

Interdigital tissue regression in the developing limb of vertebrates

Carlos I. Lorda-Diez, Juan A. Montero, Juan A. Garcia-Porrero and Juan M. Hurle

Int. J. Dev. Biol. (2015) 59: 55-62

https://doi.org/10.1387/ijdb.150065jh

Hydra, the everlasting embryo, confronts aging

Daniel E. Martínez and Diane Bridge

Int. J. Dev. Biol. (2012) 56: 479-487

https://doi.org/10.1387/ijdb.113461dm

Vertebrate limb regeneration and the origin of limb stem cells

Susan V Bryant, Tetsuya Endo and David M Gardiner

Int. J. Dev. Biol. (2002) 46: 887-896

http://www.intjdevbiol.com/web/paper/12455626

A unique aged human retinal pigmented epithelial cell line useful for studying lens differentiation in vitro

P A Tsonis, W Jang, K Del Rio-Tsonis and G Eguchi

Int. J. Dev. Biol. (2001) 45: 753-758

http://www.intjdevbiol.com/web/paper/11669377

Regulation of neural crest cell populations: occurrence, distribution and underlying mechanisms

$\mathrm{J} L$ Vaglia and B K Hall

Int. J. Dev. Biol. (1999) 43: 95-110

http://www.intjdevbiol.com/web/paper/10235385

The cellular basis of limb regeneration in urodeles

A L Mescher

Int. J. Dev. Biol. (1996) 40: 785-795

http://www.intjdevbiol.com/web/paper/8877452

5 yr ISI Impact Factor $(2016)=2.421$
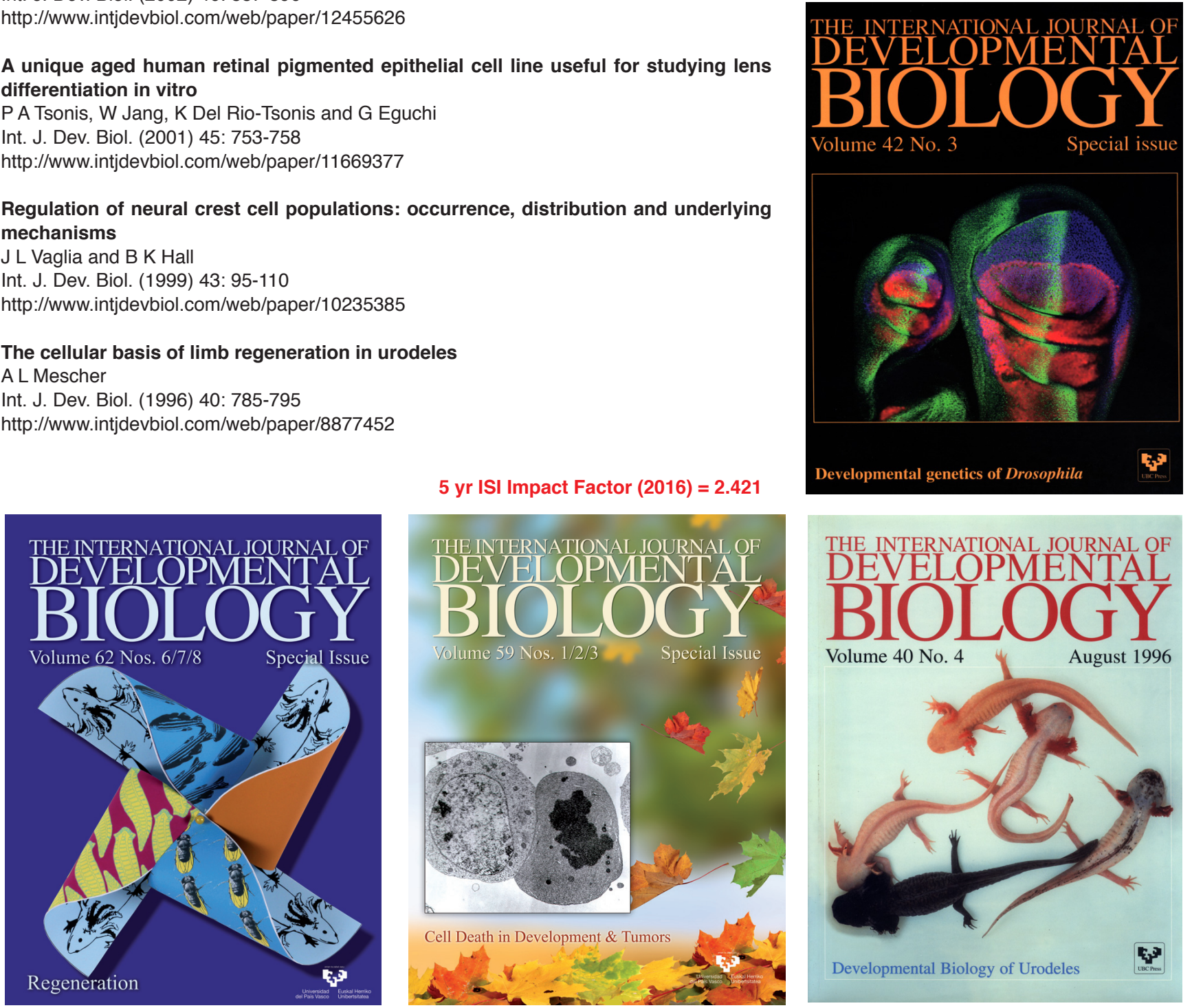